\title{
Öğrenci Motivasyonunu Artıran ve Azaltan Öğretmen Davranışlarının İncelenmesi*
}

\author{
DOI: $10.26466 / o p u s .404122$ \\ *
}

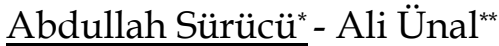

* Dr. Öğr. Üyesi, Necmettin Erbakan Üniversitesi, Ahmet Keleşoğlu Eğitim Fak., Konya/ Türkiye E-Posta: asurucu@konya.edu.tr ORCID: 0000-0002-1689-4366

"Doç. Dr., Necmettin Erbakan Üniversitesi, Ahmet Keleşoğlu Eğitim Fakültesi, Konya/ Türkiye E-Posta: aliunal@konya.edu.tr ORCID: 0000-0003-2967-2444

\section{Öz}

Motivasyon, öğrencilerin akademik başarılarında en kritik faktördür. Öğrencilerin motivasyonlarının ortaya çıkmasında en kritik faktör ise, öğretmen davranışlarıdır. Bu araştırmada, öğretmenlerin öğrenci motivasyonunu artıran ve azaltan davranışlarım tespit etmek amaçlanmıştır. Araştırma, nitel araştırma desenlerinden fenomenoloji deseninde yürütülmüştür. Çalışma grubunu Necmettin Erbakan Üniversitesi'nde pedagojik formasyon eğitimi alan ilahiyat fakültesi öğrencisi ya da mezunu 294 öğretmen adayı oluşturmuştur. Veriler, araştırmacılar tarafından geliştirilen açık uçlu anket formu ile toplanmıştır. Veriler, içerik analizi ile çözümlenmiştir. Analiz sonucunda, öğretmenlerin kişisel ilgi, hazırlık/planlama, yüksek başarı beklentisi, coşku, eşitlik-adalet, tutarlılık, açık sınıf iklimi, alan bilgisi ve dikkat çekme davranışlarının öğrenci motivasyonunu artırdı̆̆ı; coşkusuzluk, gözde öğrenci, tutarsızlık, kapalı sınıf iklimi, şiddet -fiziksel şiddet, psikolojik şiddet ve pasif saldırganlık-, ulaşılmazlık, yetersizlik -sınıf kontrolü, mizah duygusu, insan ilişkileri, konuşma sorunları, alan bilgisi- davranışlarının öğrenci motivasyonunu düşürdüğ̈̈ bulgusuna ulaşılmıştır. Elde edilen bulgulara dayal olarak öğretmenlere, öğretmen yetiştiren kurumlara ve okullara yönelik öneriler getirilmiştir.

Anahtar Kelimeler: Öğrenci, Motivasyon, Öğretmen davranışı

\footnotetext{
. Bu çalışma, 3-5 Kasım 2016 tarihinde Antalya/Side'de düzenlenen 1. International academic research congress'de sözlü bildiri olarak sunulmuştur.
}

OPUS (c) Uluslararası Toplum Araştırmaları Dergisi-International Journal of Society Researches ISSN:2528-9527 E-ISSN : 2528-9535

http://opusjournal.net 


\title{
Investigation of Teacher Behavior Increasing and Reducing Student Motivation
}

\begin{abstract}
Motivation is the most critical factor in the academic achievement of students. The most critical factor in the emergence of student motivation is teacher behavior. In this study, it was aimed to determine the teacher behavior increasing and decreasing student motivation. The study was carried out in a phenomenological pattern from qualitative research designs. 294 teacher candidates, who are pedagogical formation students or graduates of Theology Faculty at Necmettin Erbakan University, have formed the study group. The data were collected by an open-ended questionnaire developed by the researchers. The data were analyzed by content analysis. As a result of analysis, it has been reached that teachers' personal interest, preparation/planning, expectation of high success, enthusiasm, equality-justice, consistency, open class climate, field knowledge and attentiongrabbing behavior increase student motivation; dejection, favorite student, inconsistency, closed class climate, violence-physical violence, psychological violence and passive aggression, inaccessibility, inadequacy-class control, humor, human relations, speech problems and content knowledge decrease student motivation. Suggestions have been made to teachers, teacher training institutions and schools based on the findings.
\end{abstract}

Keywords: Student, Motivation, Teacher behavior

OPUS (c) Uluslararası Toplum Araştırmaları Dergisi-International Journal of Society Researches ISSN:2528-9527 E-ISSN : 2528-9535

http://opusjournal.net 


\section{Giriş}

Öğrencilerin okul başarısını, motivasyon, yoksulluk, sosyal dezavantajlar, ev ve ailevi durumlar, okullardaki yetersiz koşullar, test ve değerlendirme baskısı gibi birçok faktör etkilemektedir (Robinson, 2017). Bununla birlikte; eğitim araştırmacıları ve uygulayıcıları, öğrencinin başarısı ve başarısının devamı için en kritik faktörün öğrencinin motivasyonu olduğunu belirtmektedirler (Maulana, Opdenakker, den Brok ve Bosker, 2011; Orhan Özen, 2017; Robinson, 2017). Wang ve Eccles (2013) ayn1 bakış açısıyla, okullar ve eğitim araştırmacılarının, düşük öğrenme, düşük başarı ve yüksek terk oranlarıyla ilgili sorunları önlemek için motivasyon faktörlerine dikkat edilmesi gerektiğini ifade etmektedirler.

Motivasyon genel anlamda, kişide ilk istek ve arzuların seçilmesi, s1ralanması, eyleme geçilmesi yoluyla bilişsel ve motor süreçleri başlatan, yönlendiren, koordine eden, güçlendiren, sonlandıran ve değerlendiren dinamik bir uyarılma halidir (Dörnyei ve Ushioda, 2011). Öğrencinin sinava hazırlanması, ders dinlemesi, yaptı̆̆ işten doyum alması, ne yapacağına karar vermesi durumları onun motivasyonuyla ilişkilidir (Yazıc1, 2012). Farklı bir ifade ile motivasyon, etkili öğrenmenin en önemli bileşenlerinden biridir (Slavin, 2013).

Öğrencinin motivasyonu, öğrencinin kişiliğinden, yeteneklerinden öğrenme materyallerinin özelliklerine, ortama, öğrenmeyle ilgili teşviklere ve öğretmen davranışlarına kadar geniş bir yelpazede gruplandırılabilir (Slavin, 2013). Peki, öğrenciler okul ve öğrenmeye nasıl motive edilebilir? Robinson (2017), öğrenci motivasyonunu artırmaya sistem bazlı bakmakta; öğrencilerin motivasyonunu artırmanın en iyi yolunu, öğretimin kalitesini geliştirmek, zengin ve dengeli bir program oluşturmak, destekleyici ve bilgilendirici değerlendirme sistemine sahip olmak olarak görmektedir. Konuya öğrenci açısından bakan yazarlar ise (Opdenakker, Maulana ve den Brok, 2012; Stroet, Opdenakker ve Minnaert, 2015) ev ortamları, akran grupları ve dersliklerde neler olduğunun öğrenci motivasyonunda önemli olduğunu belirtmektedirler. Maulana, Opdenakker ve Bosker (2016) da öğrencilerin motivasyonunu artırmak için, sınıfta öğrenmenin merkezi figürü olan öğretmene odaklanmak gerektiğine vurgu yapmaktadırlar. Bunun nedeni olarak da öğretmenlerin hem derslikte olanların önemli belirleyicileri olmaları hem de öğret- 
men davranışlarının öğrencilerin akademik motivasyonu ve başarısı ile ilişkili olmasını göstermektedirler. Diğer araştırmacılar da benzer bir bakış açısıyla öğretmenin görevinin, daha çok öğrencilerin okul yaşamında başarılı olabilmeleri için gerekli beceri ve bilgileri, öğrenmeye motive olma durumlarını keşfetmek, zorlamak ve motivasyonlarını sürdürmeye yardımcı olmak olması gerektiğini belirtmektedirler (Deniz, Avşaroğlu ve Fidan, 2006; Slavin, 2013). Nitekim geleneksel olarak sınıf içindeki karışıklık ve engellerin birincil kaynağı olarak öğrenciler görülürken, öğretmenlerin de istenmeyen davranışlar sergilemeleri söz konusudur (Kearney, Plax, Hays ve Ivey, 1991; Ünal, 2012; Ünal ve Gürsel, 2015).

\section{Öğretmenlerin Öğrencilerin Motivasyonunu Azaltan Davranışları}

Kearney vd. (1991), öğretimi ve dolayısıyla öğrenmeyi olumsuz etkileyen öğretmen davranışlarını, "istenmeyen öğretmen davranışları" olarak kavramsallaştırmış, öğretmenlerin öğrencileri rahatsız eden, motivasyonunu azaltan veya dikkatini dağıtan istenmeyen 28 davranış tespit etmişler ve bunları, yetersizlik, sorumsuzluk ve saldırganlık olmak üzere üç ana kategoride toplamışlardır. Yetersizlik davranışları, öğretmenin yaptığı işe ilişkin bilgi sahibi olmadığını, öğretmenin dersi ve öğrencileri önemsemediğini gösteren davranışlardır. Saldırganlık davranışları, alay/küçük düşürme, sözlü taciz, makul olmayan/keyfi kurallar, cinsel taciz, olumsuz kişilik ve kayırma/önyargılı olma davranışlarıdır. Sorumsuzluk davranışları ise devamsızlık, geç kalma, hazırlıksızlık ve dağınıklık, programdan sapma, çalışmalara geç dönüt verme ve aşırı bilgi yükleme davranışlarını içermektedir.

Gorham ve Christophel (1992), öğretmenlerin, motivasyonu azaltan olumsuz davranışlarının, motivasyonu artıran olumlu davranışlarından daha fazla etki yaptığını belirlemişlerdir. Gorham ve Christophel, bu çalışmada, öğretmenlerin öğrenci motivasyonunu azaltan davranışlarını dört kategoride incelemişlerdir:

1. Öğretmen bilgisiz, sorumsuz, materyal veya derslik kontrolü altında değil: Sınıfta disiplin eksik; bilgi eksikliği var; öğrencilerin seviyesine adapte edebilmek için materyallere yeterince aşina de- 
ğil; sınıfı hazırlamamış; sınıfa geç geliyor; yeterince çaba harcamıyor; ödevlere yetersiz dönüt veriyor; dersi erken bitiriyor; notları geç açıklıyor; hazırlıksız derse geliyor; kötü örnek oluyor.

2. Öğretmenin sunum yeteneği kötü, mizah duygusu yok, dil engelleri var, konu dışına çıkıyor, çok fazla örnek veriyor ve hevessiz: Öğretmen, konuyu öğretmeye hevesli değil; sunum becerilerini geliştirmeye ihtiyacı var; dersleri organize etmemiş; dersi sıkıcı sunmakta; dersin hızını ayarlayamamakta; öğrenci cansız, ilgisizse öğretmen de öyle; mizah duygusu yok; dil becerilerinin yetersizliğinden kolayca konu dışına çıkar; derste çok fazla örnek verir.

3. Öğrencilere karşı olumsuz tutum ve ilişki, ulaşılmaz: Öğrencilere karşı önemsemeyen bir tavır sergileme; öğrencilerle bireysel olarak ilgilenmeme; sözlü veya yazılı yorumları dikkate almama; duyarsızlaşma; öğrencilere uzak veya soğuk davranma; yardımsever olmama; çok sert bir yaklaşım; kibirli tutum, keyfi olma, adaletsizlik; sadece en çok konuşan öğrencilere dikkat etme diğerlerinin cesaretini kırma; yapıcı ya da saygılı olmayan eleştiri; duyarlılık eksikliği; dersi hakkında danışma veya öğüt için arandığında bulunmama.

4. Olumsuz kişisel görünüm.

Gorham ve Millette (1997), Gorham ve Christophel (1992) tarafından yapılan çalışmayı esas alarak yürüttükleri çalışmada, öğrenciler motivasyon düşüklügünün çoğunu öğretmen davranışlarına, özellikle zayıf sunum becerilerine, öğretmenin şevk eksikliğine ve ders materyalinin genel seçimi ve organizasyonuna atfetmişlerdir. Oxford (1998) ise motivasyonu azaltan dört tür öğretmen davranışı keşfetmiştir (Akt: Dönyei ve Ushioda, 2011, Yan, 2009):

1. Öğretmenin öğrencilerle olan kişisel ilişkileri: Yeterince ilgi göstermeme, saldırganlık, aşırı eleştiri ve himaye/iltimas.

2. Öğretmenlerin ders veya materyal hakkındaki tutumları: Şevk eksikliği, özensiz yönetim ve dar görüşlülük.

3. Öğretmen ve öğrenciler arasındaki stil çatışmaları: Yapılandırma ya da detay miktarı ile çatışmalar ya da sınıfın ciddiyeti ve duruşu ile ilgili çatışmalar.

4. Sınıf etkinliklerinin niteliği: İlgisizlik, aşırı yüklenme ve tekrarlama. 
Lamb (2017) de, ikinci dil olarak İngilizce öğrenenlerle ilgili yaptığı literatür taramasında, sınıfta motivasyonu azaltan dokuz faktör tespit etmiştir:

- Çok kontrollü olmak, böylece sınıf üyelerinin sınıf olaylarını kontrol etme hissini azaltmak,

- Az kontrol uygulayarak ilgisizlik izlenimi uyandırmak,

- Dostça veya cana yakın görünmemek,

- Monoton öğrenme faaliyetleri sağlamak (örneğin, dilbilgisi çevirisi),

- Aşırı düzeltici yazılı geri bildirim vermek veya çok olumsuz geribildirim vermek,

- Öğrencilerin birey olarak en belirgin kimliğini görmezden gelmek,

- Öğrencilerin amaçlarını ve metodolojik tercihlerini ihmal etmek,

- Öğretmen-öğrenci ilişkileri için uygun sınırlar belirlememek,

- Konu alanına hakim olmamak.

Chambers (1993), İngiltere'de öğrencilerin yabancı dil öğrenmek istememeleri ile ilgili yaptığ çalışmada, öğrencilerin öğretmenlerini davranışlarıyla ilgili bazı hususlarda suçladıklarını tespit etmiştir (Akt: Dörnyei ve Ushioda, 2011):

- Öğrencilerin derse ilgilerini kaybettiklerini fark etmeden her şey yolundaymış gibi derse devam etmek,

- Yeterince açik talimat vermemek,

- Kalitesiz ekipmanların kullanılması (örneğin dinleme görevleri için),

- İşleri yeterince açıklamamak,

- Öğrencileri eleştirmek,

- Anlamadıkları zaman öğrenciye bağırmak.

Dörnyei (1998), ikinci dil öğrenme motivasyonu düşmüş 50 ortaokul öğrencisi ile görüşme yaparak gerçekleştirdiği çalışmada, öğrencinin motivasyonun düşmesinin ana kaynağı olan dokuz kategori belirlemiştir (Akt: Dörnyei ve Ushioda, 2011). Belirlenen davranışların yüzde 40'1 doğrudan öğretmen ile ilgiliyken (kişiliği, öğretime bağlllık, öğrencilere verilen önem, yeterlilik, öğretim metodu, stil, öğrencilerle olan uyum), yüzde 15'i de öğretmenlerin dolaylı olarak da olsa kontrolü altındaki 
bazı sınıf etkinlikleri ile ilgilidir (örneğin; öğrencinin kendine güvenini azaltmasına neden olabilen çok düşük not verme).

Ünal (2012), öğretmenlerin istenmeyen davranışları ve bu davranışların okuldaki kural ve ilişkilere etkisini incelediği çalışmasında, öğretmenlerin öğrenciye yönelik sapma davranışlarının, tüm sapma davranışlarının yaklaşık \%25'ini oluşturduğunu, tespit etmiştir. Okul müdürleri öğretmenlerin belirlenen sapma davranışlarının neredeyse tamamını okul kurallarını ya da okulda kişiler arası ilişkileri bozmada önemli olarak görmektedirler. Çalışmada belirlenen istenmeyen davranışlar; öğrenci dövmek, öğrenciyi sınıftan atmak, öğrenciye hakaret etmek tartaklamak, azarlamak, terslemek, küfür etmek-, öğrenciyi cinsel taciz, öğrenciyi okuldan atmakla tehdit ve öğrencilere ev işleri yaptırmak olarak belirlenmiştir. Ünal (2013), geliştirdiği Öğretmenlerin Sapma Davranışları Ölçeği'nde öğretmenlerin istenmeyen davranışlarını; kişilerarası sapma, öğretim sapması, zaman sapması, işbirliği sapması boyutlarında bütünleştirmiştir. Öğretmenlerin öğrencilerin motivasyonunu doğrudan etkilemesi muhtemel davranışları, sınıftaki performansına yönelik öğretim sapması (sınıfı iyi yönetmemek/yönetememek, verimli ders işlememek /işleyememek, ders müfredatına uymamak, hazırlıksız derse girmek, öğrenciye fiziksel ceza uygulamak -dövme, kulağını çekme-) ve öğretmenin sınıfta geçirdiği süreye yönelik zaman sapması boyutlarında (dersten erken çıkma, gerekçesiz olarak derse gelmeme, derste, amaç dışı davranışlarda bulunma, derse geç girme) yer almaktadır.

Öğrencileri etkileyen olumsuz öğretmen davranışlarını belirlemek amacıyla Ünal ve Gürsel (2015) tarafından yürütülen çalışmada ise öğretmenlerin istenmeyen davranışları, mesleki yetersizlik ve şiddet olarak iki kategoride bütünleştirilmiştir. Mesleki yetersizlik kategorisindeki olumsuz öğretmen davranışları arasında; disiplini sağlayamama, olumsuz yargilarda bulunarak öğrenciyi motive etmeye çalışma, sınıfta başarısız öğrencileri tembeller sırasına oturtma bulunmaktadır. Şiddet kategorisinde bütünleştirilen davranışlar; fiziksel şiddet, psikolojik şiddet ve pasif saldırganlık olarak üç alt kategoriye ayrılmaktadır. Fiziksel şiddet kategorisinde, öğrenciyi bireysel ya da toplu olarak dövme; psikolojik şiddet kategorisinde azarlama ya da aşağılama; pasif saldırganlık kategorisinde, düşük beklenti, objektif değerlendirme yapmama vb. davranışlar yer almaktadır. Analiz yapılırken tespit edilen ilginç bir bulgu, 
öğretmen şiddetine maruz kalan öğrencilerin, başkalarının bulunduğu ortamlarda utanma duygusu yaşayarak daha fazla etkilendiklerine, kendilerinin şiddete uğramasından daha fazla vurgu yapmalarıdır.

\section{Öğretmenlerin Öğrencileri Motive Edici Davranışları}

Robinson (2017), eğitimin ana amacının, öğrencilerin öğrenmesine yardım etmek olduğunu, bunu yapmanın da öğretmenin görevi olduğunu belirtmektedir. Ona göre, eğitimin kalbi, öğretmen-öğrenci arasındaki ilişkide atmaktadır ve diğer her şey bu ilişkinin verimli ve başarılı olmasına bağlıdır. Eğer bu ilişki yoksa sistem bir işe yaramıyor demektir. Araştırmalar, sorunlu bir öğretmen-öğrenci ilişkisinin, öğrencinin öğrenmesi ve gelişimi için tahrip edici olduğunu, sağlıklı bir öğretmenöğrenci ilişkisinin ise verimli bir sınıf ortamının karakteristiği olduğunu göstermektedir (Maulana, Opdenakker ve Bosker, 2013; Maulana vd., 2011; Opdenakker vd., 2012). Öğretmenlerini olumlu kişilerarası davranışları benimsemiş olarak algılayan öğrenciler, daha fazla motive olmakta, okul görevlerine girmekte ve daha yüksek akademik başarılara ulaşmaktadır. Aksine, öğretmenlerle olan ilişkilerini, aşırı derecede şiddetli, düşmanca veya çelişkili olarak algılayan öğrencilerin motivasyonu düşmekte ve daha düşük performans sergilemektedirler (Passini, Molinari ve Speltini, 2015). Farklı bir ifade ile öğrencilerin akademik motivasyonu, öğretmenlerin kişiler arası davranışları ile ilişkili olup, kişiler arası davranışlar, okullar ve öğretmenler için öncelikli olmalıdır (Erben Keçici, Beyhan ve Sönmez Ektem, 2013a; Maulana vd., 2016). Öğrenciler onlarla ilişki kuran ve en önemlisi onlara inanan öğretmenlere ihtiyaç duymaktadırlar (Robinson, 2017).

Gorham ve Millette (1997) öğretmenlerin motive edici öğretmen davranışlarını tespit etmek için yaptıkları çalışmada motive edici dört öğretmen davranışı belirlemişlerdir:

- Materyalin kullanımında güvenilir, bilgili ve yeterli,

- Sunum becerisi, coşku, mizah duygusu, konuşmanın açıklığı, kendine özgü örnekler,

- Öğrencilerle olumlu ilişki ve onlara karşı olumlu tutum, ulaşılabilirlik ve erişilebilirlik, 
- Yüksek beklentilere dayalı iletişim, olumlu dönüt ve cesaretlendirme.

Dörnyei (2001), kitabında öğretmenin sınıfta yaptığı her şeyin öğrencilerin motivasyonu üzerinde bir etkisi olmakla birlikte öğretmenlerin coşkusu, öğrencilerin öğrenmesine olan bağlılıkları ve beklentileri, öğrencilerle olan ilişkileri ve öğrencilerin ebeveynleriyle olan ilişkilerinin öğrenci motivasyonunda etkili olduğunu belirtmektedir. Dörneyi'nin (2001) bu faktörlerle ilgili açıklamaları aşağıda verilmiştir:

Coşku: Öğrencilerin en etkili olarak hatırladıkları öğretmenleri, en coşkulu olanlardır. Öğretmenlerin özveri ve tutkuları öğrencilere de bulaşır.

Öğrencilerin öğrenmesine bağlılık ve olumlu beklenti: Öğretmen, lider pozisyonunda sınıfın ruhunu temsil eder. Öğrencilerin öğrenme ve ilerlemelerinde kararlılık gösterdiğinde aynı şeyi onların da yapmaları için onlara bir şans sağlar. Bunun için öğretmen öğrencilere somut yardımlar teklif etmesi, hemen dönüt vermesi, öğrencilerin kendilerini aramasına izin vermek vb. davranışlar sergilemelidir. Öğrenmeye bağlılı̆̆ın yanı sıra motivasyonu artırmak için öğrencilerin neler başarabileceği konusunda yeterince yüksek beklentilere sahip olmalı ve bu beklentilerini öğrencilerine iletmelidir.

Öğrencilerle iyi ilişkiler kurmak: Motive edici bir öğretmen, öğrencileriyle sadece akademik bir düzeyde değil, kişisel olarak da öğrencilerle olumlu bir ilişki kurmalıdır. Öğrencileriyle sıcak, kişisel etkileşimleri paylaşan, endişelerini empatik bir şekilde yanıtlayan ve karşılıklı güven ve saygınlıkla öğrencilerle olan ilişkilerini kurmayı başaran öğretmenler, öğrencilere ilham verebilirler. Öğrencilerle kişisel bir ilişki kurmak ve saygı kazanmak için onları kabul etmek, dinlemek ve dikkat etmek, ulaşılabilir olmak gerekmektedir.

Ebeveynler ile iyi ilişkiler: Çoğu çocuk için ailelerinin görüşleri önemlidir ve bu nedenle anne-babalar herhangi bir motivasyon çabasında güçlü müttefikler olabilirler.

Yıldırım, Ünal ve Sürücü (2015), öğretmenlerin 10 etkili davranışını belirlemişlerdir: Arzulu ve coşkulu olma, samimi ve esprili olma, dürüst 
ve güvenilir olma, öğrencilerden yüksek düzeyde başarı beklentisi, cesaretlendirme ve destekleme, konuları kısa ve anlaşılır anlatma, sistemli olma (amaca bağlılık, ciddi olma, planlı olma, organize olma), alanında yeterli bilgi sahibi olma (genel kültür bilgisi, alan bilgisi, öğretmenlik meslek bilgisi) değişiklik konusunda esnek olma, olumlu tutum sahibi olma, iyi bir model olma, sabırlı olma ve kendine güvenme.

Motive edici öğretmen davranışları hakkında kültürel farklılıklara da dikkat etmek gerekmektedir. Örneğin, Lamb ve Wedel (2014), Endonezyalı öğrencilerin metodolojide yeniliğe değer verirken, Çinli öğrencilerin geleneksel yöntemlerin etkili bir şekilde kullanılmasını değerli bulduklarını; Endonezyalıların öğretmenlerine eğlenceli dersler verdiklerinden övgüde bulunurken, Çinlilerin, dersi ilginç hale getiren öğretmenleri takdir ettiklerini; Endonezyalıların açık ve anlaşılabilir sınıflara değer verirken, Çinli öğrencilerin, nasıl öğrenecekleri konusunda ögüt veren öğretmenleri değerli bulduklarını tespit etmiştir. Ayrıca; öğretmen davranışlarının öğrenci motivasyonuna etkisi kültürlere göre farklılık gösterebilmektedir. Örneğin; istenmeyen davranışlar farklı kültürlerde benzer şekilde algılanmasına rağmen, ABD, Japonya ve Almanya'daki öğrencilerin motivasyonlarındaki bozulma, Çin'deki öğrencilere göre öğretmen davranışlarıyla daha fazla ilişkilidir (Zhang, 2007).

Bu çalışmada, Maulana vd.'nin (2016) görüşleri doğrultusunda öğrenci motivasyonunu olumlu ve olumsuz etkileyen öğretmen davranışlarına odaklanılmıştır. Bu odaklanmanın birinci nedeni, Maulana vd.'nin (2016) ortaya koyduğu gibi, birçok öğrencinin akademik motivasyonunun zayıf olmasına rağmen, öğretmen davranışlarının dinamik doğası ve öğrencilerin akademik motivasyonunun gelişimiyle ilişkili bilgilerin sınırlı olmasıdır. İkincisi ise araştırmaların öğretmen davranışı ile öğrenci motivasyonu arasında bir ilişki göstermesinin, öğretmenin davranışları ile öğrenci motivasyonunu kolaylıkla azaltabileceğini göstermesine rağmen öğretmenlerin bu denklemdeki etkilerinin tam olarak farkında olmamalarıdır (Gorham ve Millette, 1997). Oysa öğretmenler öğrencilerin okul yaşamında başarılı olabilmeleri için gerekli beceri ve bilgileri öğrenmeye motive olma durumlarını keşfetmek, zorlamak ve motivasyonlarını sürdürmeye yardımcı olmak (Slavin, 2013) bir çocuğun nasıl öğrendiğini, motivasyon gibi faktörlerin nasıl ortaya çıktığını, öğretim sürecini nasıl 
kolaylaştırdığını bilmelidir (Rehman ve Haider, 2013). Bu nedenle, öğretmenlerin öğrencilerin akademik motivasyonunun gelişimiyle ilgili olan davranışlarını tespit etmek, öğrencilerini motive etme konusunda sorun yaşayan öğretmenlere ve kendisini geliştirmek isteyen öğretmen adaylarına yardımcı olabilir.

\section{Amaç}

Öğretmen-öğrenci arasındaki kişiler arası ilişkilerle ilgili araştırmalar, öğretmenlerin kişiler arası davranışlarının kalitesinin okul yılı boyunca azalma eğiliminde olduğunu (Maulana vd., 2016), öğrenci motivasyonunun şaşırtıcı biçimde sınıflar ilerledikçe azaldığını, birçok öğrencinin motivasyonunun zayıf olduğunu göstermektedir (Opdenakker vd., 2012). Daha önce yapılan araştırmalar, bir öğretmenin sergilediği davranışlarla öğrenci motivasyonunda artış ya da azalmaya neden olmakla birlikte; öğretmenlerin davranışlarının bu etkilerini nispeten bilmediklerini göstermektedir (Gorham ve Millette, 1997). Öğrencinin akademik motivasyonun zayıflamasının, öğretmenlerin davranışları ile ilişkili olduğunu bilmekle birlikte öğretmen davranışlarının dinamik doğası ve öğrencilerin akademik motivasyonunun gelişimiyle nasıl ilişkili olduğu hakkında bilgiler sınırlıdır (Maulana vd., 2016).

$\mathrm{Bu}$ araştırmanın amacı, öğretmenlerin, öğrenci motivasyonunu artıran ve azaltan davranışlarını tespit etmektir.

\section{Yöntem}

\section{Desen}

Bu çalışma, nitel araştırma desenlerinden fenomenoloji deseninde yürütülmüştür. Fenomenoloji deseninde, bireylerin kendine özgü algıları tespit edilmeye çalışılır ve bu amaçla farkında olunan ancak ayrıntılı bilgiye sahip olunmayan olgulara odaklanılır (Creswell, 2013). Bu desen; etkili, duygusal ve sıklıkla yoğun insan deneyimlerini çalışmak (Merriam, 2013), ve kişi ya da kişilerin bir olguya ilişkin deneyimlerinin anlamı, yapısı ve özünü araştırmak için (Patton, 2014) uygundur. Başka bir ifade ile bu desende, kişilerin bir olguya ilişkin deneyimlerinden yola 
çıkarak algıları ve algılarına yükledikleri anlamlar anlaşılmaya çalışılır. $\mathrm{Bu}$ araştırmada incelenen olgu öğretmenlerin öğrenci motivasyonunu olumlu ya da olumsuz etkileyen davranışlarıdır. Bu kapsamda öğrencilerin deneyimlerine ilişkin algıları ve bu algılara yükledikleri anlamlar aracılığıyla derinlemesine bilgi elde edilmeye çalışılmıştır.

\section{Çalışma Grubu}

Bu araştırmanın çalışma gurubunu, 2016-2017 öğretim yılında Necmettin Erbakan Üniversitesi'nde pedagojik formasyon eğitimi alan ilahiyat fakültesi öğrencisi ya da mezunu öğrenciler oluşturmaktadır. Çalışma grubu, söz konusu programda derslere katılan 240'1 kız, 54'ü erkek olmak üzere toplam 294 öğretmen adayından oluşmaktadır.

\section{Verilerin Toplanması}

Araştırmanın verileri, araştırmaçlar tarafından geliştirilen açık uçlu anket formu ile toplanmıştır. Anket formunda, çalışma grubunda yer alan öğretmen adaylarından, imam hatip lisesi mezunları için meslek dersleri öğretmenlerini, diğer liselerden mezun olanlar için ise din kültürü ve ahlak bilgisi öğretmenlerini düşünerek cevap verecekleri iki soru sorulmuştur. İlk olarak, "Sizi daha çok çalışmalıyım diye düşündürten, sizi motive ettiğini düşündüğünüz bir öğretmen oldu mu? Olduysa, bu öğretmenin sizi motive eden davranışlarını ayrıntısıyla yazınız." sorusu sorulmuştur. İkinci olarak da aynı soru motivasyonu azaltan öğretmen davranışı olarak sorulmuştur. Anket formu, çalışma grubunda yer alan öğretmen adaylarına araştırmacıların bizzat kendileri tarafından doldurtulmuştur.

\section{Verilerin Analizi}

Araştırma verilerinin çözümlenmesinde içerik analizi kullanılmıştır. Veriler, öncelikle iki araştırmacı tarafından birlikte okunarak kodlanmıştır. Araştırmacılar sonrasında kodları benzerlikleri dikkate alarak kategoriler altında ve kategoriler temalar altında bütünleştirmişlerdir. Üçün- 
cü aşamada, araştırmacılar birlikte Patton'un (2014) önerileri doğrultusunda, doğrulama yaparak, kategorilere uymayan verileri veya sapan durumlarını dikkatle inceleyerek analizin gerçeklik ve uygunluğunu test etmişlerdir. Sonuçta öğrencilerin motivasyonlarını artıran öğretmen davranışlarıyla ilgili 38 kod tespit edilmiş, bu kodlar dokuz temada bütünleştirilmiştir. Öğrencilerin motivasyonlarını azaltan öğretmen davranışları ile ilgili olarak ise 60 kod tespit edilmiş, bu kodlar 13 kategoride toplanmış ve yedi temada bütünleştirilmiştir. Analiz sürecinde Nvivo nitel veri analizi programından yararlanılmıştır.

Analiz sırasında, veriler toplanırken öğrencilerin, imam hatip lisesi meslek dersleri öğretmenleri ve din kültürü ahlak bilgisi dersi öğretmenlerini düşünerek cevap vermeleri istenmiş olmasına rağmen, cevapların diğer öğretmenlerin davranışlarını da kapsayacak şekilde verildiği tespit edilmiştir. Bu nedenle; araştırmanın ilk amacı olarak belirlenen, imam hatip lisesi meslek dersi öğretmenleri ve din kültürü ve ahlak bilgisi öğretmenlerinin öğrencilerin motivasyonlarını artıran ve azaltan davranışlarını tespit etme amacı ve çalışmanın adı, tüm öğretmenlerin davranışlarına yönelik olarak değiştirilmiştir.

Araştırmada iç geçerliği sağlamak birden fazla araştırmacının katılımı ve araştırmacıların duruşunun açıklanması stratejileri kullanılmıştır (Merriam, 2013). Bu doğrultuda araştırmacılar veri toplama ve analiz süreçlerine birlikte katılmışlardır. Araştırmacılar öğretim üyesi olarak özellikle sınıf yönetimi derslerinde öğrenci motivasyonunu etkileyebilecek öğretmen davranışlarının neler olduğu konusunda açılamalar yaptıkları için doğal olarak ön yargılara sahiptirler. Ayrıca, araştırmacıların her ikisi de öğrenci motivasyonunu etkileyen öğretmen davranışları konusunda olmasa da öğretmen davranışları konusunda önceden araştırma yaptıkları için (Yıldırım vd., 2015) analiz sürecinde kendilerini etkilemesi muhtemel ön yargılara sahiptirler. Bu önyargılardan bir tanesi, öğretmenlerin öğrencilerin motivasyonunu artıran davranışları yapmamasının öğrenci motivasyonunu düşüreceğidir. Bir başkası, öğretmenin iletişim dilinin öğrenci motivasyonunda en önemli etken olduğudur.

Dış geçerliği sağlamak için katılımcıların tanıtımı ayrıntılı olarak yapılmaya çalışılmıştır. Güvenirliği sağlamak için başka bir araştırmacının süreç ve sonuçları incelemesi sağlanmış; araştırmacılarla aynı bölümde çalışan deneyimli bir öğretim üyesinden, araştırmanın deseninden top- 
lanan verilere, bunların analizine ve sonuçların yazımına kadar olan süreçlere eleştirel bir gözle bakması ve araştırmacılara geri bildirim vermesi istenmiştir. Elde edilen bulguların başka durumlara uyarlanabilmesi olasılığını artırmak için zengin ve yoğun tanımlamalar yapılmıştır (Merriam, 2013).

\section{Bulgular}

Bulgular, araştırmanın amacı doğrultusunda öğrencilerin motivasyonunu artıran öğretmen davranışları ve öğrencilerin motivasyonunu azaltan öğretmen davranışları başlıklarında sunulmuştur. Okuyucunun oluşturulan kategori ve temaları daha rahat takip edebilmesi için oluşturulan temalar ve aralarındaki ilişkiler Şekil 1'de sunulmuştur.

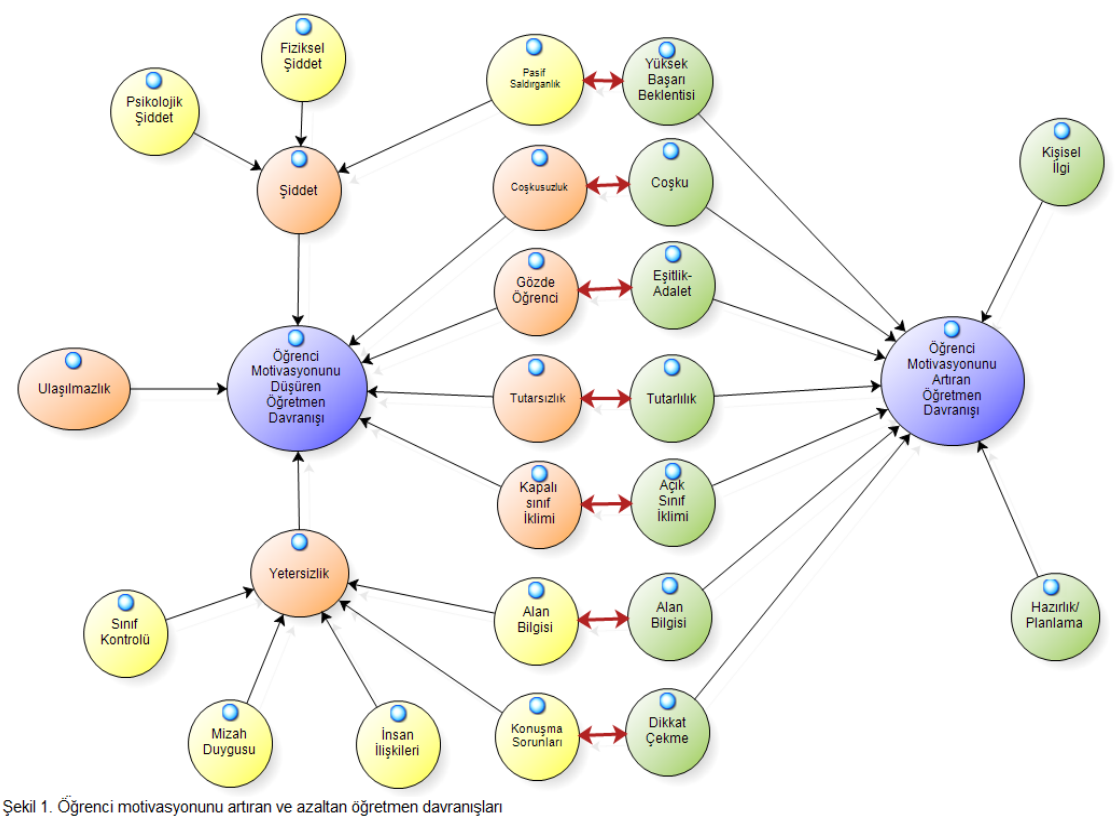

\section{Öğrencilerin Motivasyonlarını Artıran Öğretmen Davranışları}

Öğretmenlerin, öğrencilerin motivasyonunun artıran davranışları; kişisel ilgi, hazırlık/planlama, yüksek başarı beklentisi, coşku, eşitlik-adalet, 
tutarlılık, açık sınıf iklimi, alan bilgisi ve dikkat çekme temalarından oluşmaktadır. Bu temalara ilişkin açıklamalar aşağıda verilmiştir.

Kişisel İlgi: Bu tema altında toplanan öğrenci görüşlerine göre, öğretmenler öğrencilerin isimlerini bildiğinde, öğrencilerle bireysel olarak ilgilendiklerinde, onlarla konuştuğunda, başarısız olanı küçümsemeden onunla özel olarak ilgilendiğinde, derse bütün öğrencileri katmaya çalı̧̧tığında öğrenci motivasyonunu artırmaktadır. "Derse girdiği ilk gün isimlerimizi ögrenmeye gayret edişi hayranlık uyandırıcıydı." diyen bir kız öğrenci, öğretmenin öğrencilerin isimlerini öğrenmesinin çok önemli olduğunu ortaya koymaktadır. Ayrıca, "Hocamız benimle gerekenden fazla ilgileniyordu. Beni sürekli derslere ve iyi çalışkan arkadaşlara yönlendiriyordu. Ben okulun en yaramaz grubunun üyesiydim. Son simfta anladım ki hocanin benden bir beklentisi var. Onu mahcup etmemek için derslere yöneldim. Sonuçta her iki dönemi de takdirle bitirdim." diyen bir erkek öğrenci ve "Anlamayan ya da başarısız olanı küçümsemez onlarla özel olarak ilgilenirdi." diyen bir kız öğrencinin ifadeleri bu temayı açıklayıcı özelliktedir.

Hazırlık/Planlama: Bu kapsamda öğrenci motivasyonunu artıran öğretmen davranışları; derse hazırlıklı gelmesi, sunumu bir plan dâhilinde yapması ve karmaşayı önlemesi, ne yapacağı konusunda kendisine güvenli görünmesidir. "Kendisi, derslere hep hazır gelir, düzenli ve sistematik bir tarzda ders anlatırdı..." diyen kız öğrenci, öğretmenin hazırlıklı olmasının ve dersini bu hazırlık doğrultusunda planlı bir şekilde işlemesinin etkisine dikkat çekmiştir. "Çok düzenli ve tertipli ve nerede yanlış yaptı̆̆ımı, nereden puan kırdığını bildiğim birisiydi. Çok dikkatli olması benim derse önem göstermemi sağlardr. Sertti ama sert olması onu sevmemize engel değildi. Sadece saygılı olmamızı sağlardı." diyen kız öğrenci, öğretmenin düzenli olmasının, dönüt vermesinin öğretmenin sertliğini bile olumlu algılanmasına neden olduğunu ortaya koymaktadır.

Yüksek başarı beklentisi: Bu temaya göre, öğrenciye güvenen, onların başarabileceğine inanan ve bu inancını öğrenciye aktarıp, hissettirebilen öğretmenler öğrenci motivasyonunu artırmaktadır. Bir kız öğrencinin "Daima başarabileceğimizi, yapabileceğimizi söyleyip bizi motive eden bir öğretmendi. O öğretmenin sürekli öğrencilerle uğraşması hoşuma giderdi." ya da 
bir başka öğrencinin, "Hocam daha İHL 1. sımıfken geleceğin vaizesi demişti bana. Hala unutmam, hala motive olurum." şeklindeki açılamaları, öğretmenin başarı beklentisinin öğrenciyi motive etmesindeki önemini ortaya koymaktadır. Yalnız, burada dikkat edilmesi gereken husus, yüksek beklentinin oluşturulması ve öğrenciye aktarılmasında, öğretmenin beklentisini yapay değil, doğal ve samimi bir şekilde ortaya koymasına dikkat edilmesi gerekliliğidir. Farklı bir ifade ile öğrenci, öğretmeninin yüksek başarı beklentisini kendisini motive etmek için değil gerçekten buna inandığı için ifade ettiğine inanmalıdır. Bir erkek öğrenci bu durumu, "Hocamın davranışları gayet doğal ve içten olmuştur. Ders dışında da bana güvendiğini hissettirmesi de ayn şekilde o dersle ilgili benim daha iyi olmamı sağlamıştır." şeklinde ifade etmiştir.

Coşku: Bir kız öğrencinin, "Başarılı olmamız için ciddi şekilde gayret gösterirdi. Bize öğreteceklerini sanki kendisi de ilk defa öğreniyormuşçasına istekli bir biçimde verirdi." ya da başka bir kız öğrencinin, "Öğretmenim dersi o kadar severek ve şevkli anlatırdı ki bende derse karşı ilgi duyar, biraz daha araştırıp gideyim diye düşünürdüm." şeklindeki açıklamaları, öğretmenin işini sevmesi, iyi öğretmek için çaba harcaması, öğretirken yaptığı işten zevk almasının öğrenci motivasyonunu artırdığını göstermektedir. Ayrıca; "Öğle araların bize ders anlatmak için feda ediyordu." ya da "Sırf dersimi anlatırım, çıkar giderim demedi." şeklinde açıklama yapan öğrenciler de öğretmenin öğrencilerin öğrenmesi için fedakârlıkta bulunması ve işini önemsemesinin öğrenci motivasyonunu artırdığını ortaya koymuşlardır. $\mathrm{Bu}$ tema altında toplanan görüşleri belki de "Derslerde gayet mutlu bir öğretmendi. Mesleğini sevdiği belliydi ve bizi bir şeyler öğretmek için çaba gösteriyordu." diyen öğrenci özetlemektedir.

Eşitlik-adalet: $\mathrm{Bu}$ tema altında bütünleştirilen görüşlere göre öğrenciler, öğretmenlerinin çalışmalarını adil bir şekilde değerlendirmeleri ve sınıfta bütün öğrencilere eşit davranmalarının motivasyonlarını artırdığına vurgu yapmışlardır. Örneğin bir kız öğrenci bu durumu, “... not verirken çok sistemli ve adaletliydi. Meşale tecvidi ayrl, yüzünden okuma vs. ayrn ayrn değerlendirir ona göre yanlışlarımızdan not kırardı. Aldığımız notu hak ettiğimizi ve nerede yanlışımı olduğunu bilirdik" şeklinde ifade ederek adalet 
davranışına dikkat çekmiştir. "Derste bütün öğrencilere eşit davranırdı. ... başarılı öğrencileri gizlice ödüllendirirdi. Bu ödüller maddi içerikli olmayıp, bir bardak çay içme gibi küçük ama değerli vakit geçirmelerdi." diyen öğrenci de öğretmenin eşit davranışına dikkat çekmiştir.

Tutarlılık: Bu temada bütünleştirilen görüşlere göre, öğrenciler öğretmenlerinin söyledikleri ile davranışlarının mutlaka uyumlu olmasını beklemekte, söyledikleri ile davranışları tutarlı olan öğretmenleri daha inandırıcı, ikna edici bulmaktadırlar. "Bu öğretmenimizin dersteki tavsiyeleri ve ders dışında kendisinin yaptığı işlerin tutarlı olması da etkileyici bir unsurdu." diyen bir kız ya da "Bize öğrettiklerini kendi hayatında tatbik ediyor$d u . "$ şeklinde açıklama yapan erkek öğrencilerin görüşleri temada ifade edilenleri açıklamaktadır.

Açık sınıf iklimi oluşturma: Bu temaya göre, öğrenciyi notla tehdit etmeyen, öğrencileri başarısına göre değerlendirmeyen, derste yapacakları ve yaptıracakları konusunda net olan, öğrenci çalışmalarını değerlendirirken sistemli olan, sinıfta rahat bir atmosfer oluşturmaya yönelik, rahat, nezaketli öğretmen davranışları öğrenciyi motive etmektedir. Bu konuda bir kız öğrenci, "Hocamızın dersine değer vermemizin bir nedeni de hocamızın sınavı ve notu çok dert eden, öğrenciyi zorlayayım derdine düşmeyen bir insandr." diyerek not ve sınavdan ziyade öğrenmeyi, ilişkileri ön plana çıkaran davranışlara dikkat çekmiştir. "... derslerde rahat davranan öğretmenlere karşı ilgim artar." diyen kız öğrenci de dersin tamamında konuları işleyeceğim kaygısıyla hareket etmeyen öğretmenin, öğrencinin psikolojik olarak rahatlamasını sağladığına dikkat çekmiştir. "Kimseyi kırmıyordu. Onun bu tutumu beni çok etkiledi. Bu hocanın dersinden düşük not alırsam çok üzülürüm diye düşünmüştüm. Onun bu yumuşak tavrı beni çok motive etti. Düşük not alırsam çok üzülür diye düşünüyordum. Bu kadar nazik bir hocanın üzüntüsüne hiç bir zaman sebep olmak istemezdim." diyen k1z öğrenci de öğretmenin nezaketli davranışının sınıf iklimine etkisini örneklemektedir.

Alan bilgisi: Ders kitabına ve programa tümüyle bağlı kalmadan konuları işleyen, ders zamanını ders içeriğiyle dolduran, konu dışına çıkmayan, soru sormaya, eleştiri yapmaya izin veren, sorulan sorulara doyuru- 
$\mathrm{cu}$ yanitlar verebilen öğretmenler öğrenciyi motive etmektedir. Bir kız öğrenci bu durumu, "Kendine güvenen tavrı ve duruşu, donanıml oluşu benim için örnek şahsiyet diyebilmem için önemli etkenlerdir." diyerek, bir başka kız öğrenci de "Dersine donanıml gelen, her dakikasını verimli kullanan, ..." diyerek ve bir başkası da "Sorularımızı cevapsız bırakmazdı." diyerek öğretmenin alan bilgisinin öğrenci motivasyonundaki önemini örneklemişlerdir.

Dikkat çekme: Bu kapsamda öğrenci motivasyonunu artıran öğretmen davranışları; öğrenciyi düşündüren ve araştırmaya yönlendiren sorular sorması, dikkat dağıldığında dikkat tekrar toplanana kadar ders dışı konularda konuşması, dersi fıkra ve öykülerle zenginleştirmesi, dersi ayakta anlatması, ders konusu ile güncel olaylar arasında bağlantı kurmasıdır. Bir kız öğrenci bu temada bütünleştirilen davranışları, "Bu hocam ilmi yönden donanıml olmakla birlikte, bu ilmi öğrenciye aktarma konusunda müthiş bir kapasiteye sahipti. Konuya hakimdi ve konuyu bize aktarırken bize sorular yönlendirir, dikkati üzerinde toplardl. Bu sorular beni araştırmaya iten bir ölçüttü çünkü cevabı bize bırakır, diğer derslerde cevabı bizden beklerdi." şeklinde açıklamıştır. Diğer öğrenciler de, "Öğrenciyi dersten koparmazdı. Öğrencinin dersten koptuğunu anladığında dersi bırakır, biraz konuşur, öğrenci toparlanınca derse tekrar başlardı.", "Öncelikle güncel olayları takip ederek anlattığı dersi, güncel şeylere uyarlayarak anlatırdı.", "Dersi fikra ve öykülerle renklendirirdi." şeklindeki açıklamalarıyla öğretmenin dikkat çekme davranışlarının öğrenci motivasyonundaki önemini vurgulamışlardir.

\section{Öğrencilerin Motivasyonlarını Azaltan Öğretmen Davranışları}

Öğrencilerin motivasyonunu azaltan öğretmen davranışları; coşkusuzluk, gözde öğrenci, tutarsızlık, kapalı sınıf iklimi, şiddet -fiziksel şiddet, psikolojik şiddet ve pasif saldırganlık-, ulaşılmazlık, yetersizlik -sınıf kontrolü, mizah duygusu, insan ilişkileri, konuşma sorunları, alan bilgisi- temalarına ayrılmıştır. 
Coşkusuzluk: Bu temada bütünleştirilen görüşlere göre, sürekli masada oturarak ders işleyen, kitaptakileri okuyan ya da kitabın dişına çıkmayan, derse zorla gönderildiği izlenimi veren, ders dışı konularla ya da ilgisiz hayat hikâyeleriyle zamanı dolduran öğretmenler, öğrenci motivasyonunu düşürmektedir. Bu kapsamda bazı örnekler aşağıda verilmiştir.

“Öncelikle öğretmenlerin devlet memuru rahatlı̆̆nda olup kendini geliştirmek gereği duymamaları, vurdumduymaz olmaları, öğrenciye gereken ilgi, alaka ve merhameti göstermemesi beni olumsuz yönde etkileyen amillerdendi. Tek gayesi süre doldurmak olan öğretmenlerden motivasyon artırımı olarak bir şey beklemek hayaldir." (Kız)

"Çok yaşlydl, ders anlatmaya, konuşmaya takati yoktu. ... Dersi sadece boş oturmakla geçerdi." (Kız)

"Bu öğretmenim oturur ve masadan sadece kitaptakileri okurdu. Çok stkıcı bir ders olurdu ve hiç dinlemek istemezdim." (Kız)

"Konuyla alakasız, saçma sapan konulara girmesi, bize fayda să̆lamayacak hayat hikâyelerini anlatması." (Kız)

Gözde Öğrenci: Öğretmenin, çeşitli nedenlerle bazı öğrencilerle daha fazla ilgilenmesi, diğerlerini görmezden gelmesi ya da dışlaması diğer öğrencilerin motivasyonunu azaltan bir davranıştır. Bir erkek öğrencinin "Matematik hocası, kendinden çok emin, üstten bakan, söylediği şeyin hemen olmasın isteyen biriydi. Bir de ona yakın duran, biraz derse katılanlarla fazla ilgileniyor, diğerlerini dışlıyordu." açıklaması, tipik bir örnektir. Bir başka örnek de bir kız öğrencinin, "Kendisini bulunmaz Hint kumaşı sanan bir hocaydı. Sevdiği öğrencileri hiç sınava bile tabi tutmadan 90'ları, 100'leri havada uçuştururdu." açıklamasıdır. Bu açıklamalar, sınıfta gözde öğrenci olmasının öğrencilerde eşitsizlik-adaletsizlik algısı oluşturarak motivasyonu azalttığını göstermektedir.

Tutarsızlık: Öğrenciler, öğretmenlerinin söyledikleri ile davranışlarının uyumlu olmasını beklemekte, söyledikleri ile davranışları tutarlı olmayan öğretmenleri inandırıcı, ikna edici bulmamaktadırlar. Örneğin, erkek bir öğrenci, "Derse ilgi ve alakayı kesmemin sebebi, hocanın bazı temel bilgilerde kendisi ile çelişmesidir." diye bu durumu ifade ederken; iki kız öğrenci, "Anlattıklarıyla uzaktan yakından alakası olmayan (yaşayış tarzını kastediyo- 
rum)" "Sen masanın üstüne oturup ayak ayaküstüne atıp sözde gençlerin dili ile konuşarak onlara yakın olamazsın. ... Dini yaşa ve yaşat." şeklinde ifade etmişlerdir.

Kapalı Sınıf İklimi Oluşturma: Öğretmenin derste çeşitli nedenlerle kuralları ön plana çıkarması, kurallara uyulmasını sağlamak için aşırı ciddi, katı, gergin tavırlar sergilemesi, not tehdidi ile öğrencileri çalışmaya ve kurallara uymaya zorlaması, öğrenci davranışlarını sürekli kısıtlamaya çalışması, en iyisini ben bilirim yaklaşımıyla öğrencinin her davranışını sürekli sorgulaması öğrencinin dersi öğrenmesini, derse çalışmasını engellemekte öğrenci motivasyonunu düşürmektedir. Bu temada bütünleştirilen bazı açıklamalar aşağıda verilmiştir.

“Öğrenciyle konuşmaz, konuştuğunda hakaret ederek konuşurdu. Asık suratıyla sürekli negatif enerji yayardı. O simıfa girdiğinde karabulut gibi simfin havasim karartır ve adeta zaman kendine kilit vurur ve ilerlemek nedir bilmezdi." (Erkek)

"Sinıfa girdiği andan itibaren gergin tavırları başlardı. Sinıfin herhangi bir hatasinda haftalarca okulda yüzümüze bakmaz, sinfta küserdi." (Kız) "Fazla disiplinli davranmaya çalıştı̆̆ için ister istemez beni olumsuz etkiledi. Aslında öğretmenin yanlış bir davranışı söz konusu değildi; fakat takındiğı tavırlar benim motivasyonumu düşürdü." (Kız)

"Öğretmenimiz zorla ve not tehdidi ile ders çalışmaya teşvik edeceğini sanıyordu. Ne kadar zorlasa da, ne kadar notu düşük de verse ben yine çalışmadım." (Kız)

"Sınıfta çok katı kurallara sahip, sinirli ve gergin bir yapıya sahipti. Kısıtlayıcı, öğrencinin ne dediğini çok önemsemeyen, aşırı ciddi bir karakterdeydi." (Kız)

"Öğretmen derste çok ciddi, güler yüz yok, aşağılama durumuna maruz kalıyorduk. Bu yüzden çoğu arkadaş Kuran-ı Kerim dersine girmiyorduk." (Kiz)

"Bu hocanın dersinde kendimi öğrenci gibi değil de, sorgulanan bir sanık gibi hissediyordum." (Kız)

Şiddet: Bu tema, fiziksel şiddet, pasif saldırganlık ve sözel şiddet kategorilerinden oluşmaktadır. 
Fiziksel şiddet: $\mathrm{Bu}$ alt temada bütünleştirilen görüşlere göre, öğretmenin öğrencilere fiziksel şiddet uygulaması öğrencilerin motivasyonunu düşürmektedir. Bu durumu bir kız öğrenci, şu şekilde ifade etmektedir:

"Kuran-ı Kerim dersine giren hocamiz ezber verirdi, ezberi veremeyeni uzun pergel şeklinde sopası vardl, onunla ellerimize vururdu. Aynı ezberi bir sonraki hafta veremeyenlere dayăğ ikiye katlayarak devam ederdi. Ben değil ama o hoca yüzünden birçok arkadaşım başka okullara, meslek liselerine geçmek zorunda kalmıştı." Bir erkek öğrenci de konuyu, "Küçük sebeplerden dolayı sını önünde öğretmenimin beni dövmesi yıllarca o dersten nefret etmeme yetti." şeklinde ifade etmiştir.

Pasif saldırganlık: Bu alt temada bütünleştirilen görüşlere göre, öğretmenin öğrenciyi görmezden gelmesi, dikkate almaması, çabasını takdir etmemesi, düşük not vermesi, çok az kişinin başarılı olacağı zor sınavlar yapması, öğrencileri sosyal statülerine göre değerlendirmesi, öğrenciden düşük başarı beklentisi içinde olması ve öğrenciye bunun iletilmesi, öğrenciye gereğinden ve altından kalkabileceğinden fazla ödev vermesi öğrenci motivasyonunu azaltan öğretmen davranışlarıdır. Bu temada bütünleştirilen bazı açıklamalar aşağıda verilmiştir.

“O sene Arapçadan soğumama neden oldu. Soru sorduğunda kimse parmak kaldırmasa da beni seçmezdi. Bir müddet sonra çalışmanın ve derse iştirak etmenin beyhude olduğunu düşündü̈m." (Kız)

"Dersini ne kadar dinlesek, sinavlarına ne kadar çalısssak da kimseyi dersten geçirmiyordu. Dersini geçenler 60 kişilik simftta 10 kişi anca oluyordu. Aslinda dersini dinliyor ve çalışıyorduk ama her nasılsa hocayı tatmin eden cevabı bulamıyorduk." (Kız)

"Bir soru sorar, cevap veremeyince, "zaten sizden bir şey çıkmaz, biliyordum bilemeyeceğinizi" der bize değer vermezdi." (Kız)

"Senden zaten olmaz tavırları çok can sıkıcı. Uğraşıyorsun ama umursamıyor. Başaracağına inanmıyor. Haylaz veya aptal olduğunu düşünüyor. İlk başlarda ilgisizken sonradan ilgilenmeye çalıştığım bir derste, hoca yüzünden kendimi geri çekmiştim." (Kız)

"Zaten IHHL'de okuyorsunuz. Çok fazla beklentiniz olmasin. Bu okuldan sonra gideceğiniz okul sinırl vs. sözlerle motivasyonumuzu düşürüyor$d u . "(K \imath z)$ 
“Öğretme eğilimi yüksek olmasına rağmen gereksiz yere çok ödev vermesi ..." (Erkek)

Psikolojik şiddet: Ben bilirim siz bilmezsiniz havasında davranma, öğrencilerle sürekli küçümseyen tavırlarla iletişim kurma, öğrencilere hakaret etme, azarlama, çeşitli kişisel özellikleri nedeniyle aşağılama ve alay etme, gereksiz yere sinirlenme davranışları bu kategoridedir. Bu temada bütünleştirilen bazı açıklamalar aşağıda verilmiştir.

"Hukuk hocam, sanki dersi önceden bilen birisine anlatıyormuş gibi anlatırdı. Öğrenciler terimleri anlayamadığı için dersi anlamayınca ise ahmak muamelesi yapardı." (Kız)

"Sürekli köy çocuğu olduğumu yüzüme vururdu." (Kız)

"Sinıf içinde hata yapan bir arkadaşın rencide edilmesi de olumsuz olarak gördüğüm davranışıydı. Küçük bir hatada kızıp azarlaması da bu davranışlarından bir tanesi." (Erkek)

“... en ufak bir eksiklikten dolayı hemen cezalandırmayı seçmesinden dolayı dersine karşı epeyce isteksiz oldum. Öğrenciyi azarlamayı bir eğitim metodu olarak benimsemesi en büyük sorunuydu." (Erkek)

Ulaşılmazlık: Öğrenci çeşitli nedenlerle okul zamanı içinde ya da dışında öğretmenle görüşmek istediğinde öğretmenin ulaşılmaz, bulunmaz olması öğrenci motivasyonunu düşürmektedir. Bir kız öğrenci bu durumu, "Sorunlarımızı görüşmeye gittiğimizde odasında dahi olmuyordu." şeklinde yakınarak ifade etmiştir.

Yetersizlik: Bu temada bütünleştirilen görüşler, alan bilgisi yetersizliği, insan ilişkilerinde yetersizlik, mizah duygusu yetersizliği, sınıf kontrolünde yetersizlik, konuşma sorunları olarak beş alt temada incelenmiştir.

Alan bilgisi yetersizliği: $\mathrm{Bu}$ alt temaya göre, yeterli bilgiye sahip olmayan, yeterli bilgisi olmadığı için dersi anlatamayan, sadece kitaplara bağ1 olarak ders işleyen, ders dişı etkinliklerle zaman dolduran, sorulan sorulara cevap veremeyen öğretmenler öğrenci motivasyonunu düşürmektedir. Bir kız öğrencinin, "Ders anlatmayan, gırgır şamata hiçbir verimi olmayan, sorduğumuz sorulara cevap veremeyen öğretmenim yüzünden derse 
ilgisizleştim. Dersi zaman kaybı olarak gördüm." şeklindeki açıklaması temayı açıklar niteliktedir. Bir başka kız öğrenci de, "Bilgisi eksik, ... kitaplara bağh kalan hocalar benim motivasyonumu düşürmüştür." şeklindeki ifade ile konuyu açılamıştır.

İnsan ilişkilerinde yetersizlik: Bu temada bütünleştirilen görüşlere göre, öğretmenin, öğrencinin kişisel ihtiyaçları, sorunları ile ilgilenmeyip, öğrenciyi sadece ders dinleyen ve dersi öğrenmesi gereken bir kişi olarak görmesi, öğrencilere kaba, saygısız davranması, öğrencinin motivasyonunu düşürmektedir. İki kız öğrenci bu durumu, “... öğrencinin ne durumda olduğu ya da ne tür sorunları olduğunu düşünmeyen bir insandı." ve "Aşırı sert ve kuralcı bir kimliğe bürünüp öğrencinin kişisel ihtiyaçlarına dikkat etmeyen, öğrencinin sadece ders dinlemesi gerektiğini düşünen bir kişiliğge sahipti." şeklinde ifade etmişlerdir. Bir başka kız öğrenci ise "Öğrencileriyle iletişim halinde değildi, sadece ders anlatıyordu." diyerek durumu daha net ifade etmiştir. "Hocamızın öğrencilerine karşı kaba davranışları, ister istemez girdiği dersin öğrencileri tarafindan önemsenmemesine neden oluyor." açılaması, nezaketsiz, kaba öğretmen davranışının öğrenci motivasyonunun olumsuz etkilediğini örneklemektedir.

Mizah duygusu yetersizliği: Bu alt temada bütünleştirilen görüşlere göre öğretmenin çok kuralcı olması, ciddi bir şekilde durması öğrenci motivasyonunu düşürücü etkisi vardır. Bir kız öğrenci bu durumu, "Bu hocamız, derse gelir, oturur ve bir daha oturduğu yerden kalkmazdı. Dersi aşırı ciddi bir havada işlerdi. ..." diyerek ifade etmiştir. Bir başka öğrenci de "... ders dışında başka şey konuşmaz, espri yapmazdı." şeklinde ifade etmiştir.

Sinıf kontrolünde yetersizlik: Bu temada bütünleştirilen görüşlere göre öğretmenin öğrencileri kontrol edememesi, dersin kontrolünü kaybetmesi öğrenci motivasyonunu düşürmektedir. Bir kız öğrenci bu durumu, "Sinıfa geldiğinde tüm sinıfin alay konusuydu. Sinıfa hakim olamıyordu. Bă̆grır, kızar sonra da giderdi." şeklinde ifade etmiştir. Bir başkası da, "Öğgretmenin sinıf hakimiyeti sıfırdr. Sadece benim değil bütün sinıfın motivasyonu düşmüştü." biçiminde ifade etmiştir. 
Konuşma yetersizliği (sorunları): Öğretmenin sürekli aynı tekrarları yapması, aynı tonda konuşması ve konuşmasının ritmini hiç değiştirmemesi, öğrencilerin yüzüne bakmaması, argo kelimeler kullanması öğrenci motivasyonunu düşürmektedir. "Derse geldiğinde hep aynı tonda konuşur, öğrencilerin uyumasına sebep olurdu.", "Tek düze bir öğretmendi. ... Bir cümleyi evirip çevirip dört-beş defa söylüyordu." ve "Ders anlatışı bizim çok uykumuzu getirirdi. Dümdüz anlatır, arada kısa notlar tuttururdu, ancak biz dinleyelim diye çok çaba sarf etmezdi." diyen kız öğrenciler bu durumu örneklemişlerdir. Bir kız öğrencinin "Derste öğretmenimin argo konuştuğuna tanık olduktan sonra onu hiç önemsemedim." ifadesi de kelime seçiminin önemine vurgu yapmaktadır.

\section{Tartışma ve Sonuç}

Öğretmenlerin öğrenci motivasyonunu artıran ve azaltan davranışlarını tespit etmek için yapılan bu çalışmada, öğrenci motivasyonunu artıran dokuz ve azaltan yedi temel öğretmen davranışı tespit edilmiştir. Öğretmenlerin, öğrencilerin motivasyonunu artıran davranışlarl; kişisel ilgi, hazırlık/planlama, yüksek başarı beklentisi, coşku, eşitlik-adalet, tutarlılık, açık sınıf iklimi, alan bilgisi ve dikkat çekme davranışlarıdır. Öğrencilerin motivasyonunu azaltan öğretmen davranışları ise; coşkusuzluk, gözde öğrenci, tutarsızlık, kapalı sınıf iklimi, şiddet -fiziksel şiddet, psikolojik şiddet ve pasif saldırganlık-, ulaşılmazlık, yetersizlik -sınıf kontrolü, mizah duygusu, insan ilişkileri, konuşma sorunları, alan bilgisi yetersizlikleri- davranışlarıdır. Öğretmenin bir davranışı yaptığında ya da yapmadığında öğrencilerde motivasyon artışına ya da motivasyon düşmesine neden olan davranışlarının eşleşmeleri de söz konusudur. Bu eşleşmeler şu şekilde oluşmuştur: Yüksek başarı beklentisi-düşük başarı beklentisi (pasif saldırganlık), coşku-coşkusuzluk, eşitlik-gözde öğrenci, tutarlılık-tutarsızlık, açık sınıf iklimi-kapalı sınıf iklimi, alan bilgisi-alan bilgisinde yetersizlik, dikkat çekme-konuşma sorunları. Araştırma bulguları, tartışma ve sonuç başlığı altında öncelikle bu eşleşen davranışlara göre, sonrasında eşleşme olmayan davranışlara göre incelenmiştir. 
Yüksek başan beklentisi-düşük başan beklentisi (pasif saldırganlık): Öğretmenin öğrenci motivasyonunu artırmak için öğrencilerin neler başarabileceği konusunda yeterince yüksek beklentilere sahip olması, öğrencilerle iletişimini yüksek beklentilere dayalı olarak sürdürmesi ve bu beklentilerini öğrencilerine iletmesi, öğrenci motivasyonunu artıran bir etkendir (Dörnyei, 2001; Gorham ve Millette, 1997; Robinson, 2017). Bu bilgiyi destekler şekilde, Yıldırım vd. (2015), öğretmenin öğrencilerden yüksek düzeyde başarı beklentisini etkili öğretmen davranışı, Ünal ve Gürsel (2015) ise düşük beklentinin istenmeyen öğretmen davranış1 olduğunu tespit etmişlerdir. Öğretmen beklentisinin öğrenci başarısını etkilediği düşüncesi, Pymalion etkisi ya da kendini gerçekleştiren kehanet olarak adlandırılmaktadır. Pymalion etkisi, öğretmenlerin öğrencilerinin yetenekli ya da yeteneksiz olduğuna dair beklentileri doğrultusunda etkileşimde bulundukları ve bu durumun kendini gerçekleştiren kehanete dönüşerek, öğrencilerin öğretmen beklentileri doğrultusunda başarılı veya başarısız oldukları anlamına gelmektedir (Rubie-Davies, 2010). Farklı bir ifade ile Pymalion etkisine göre, öğretmen beklentileri öğrencilerin başarısını biçimlendirmektedir (Friedrich, Flunger, Nagengast, Jonkmann ve Trautwein, 2015). Öğretmenler bu biçimlendirmeyi, öğrencilere yönelik olumlu beklentileri varsa, daha fazla öğrenme imkânı sağlayarak veya daha fazla zorlayarak, daha ayrıntılı geribildirimler vererek, başarıyı takiben daha sık överek ve başarısızlık sonrası daha sık teşvik ederek yapmaktadır. Öğretmenler öğrencilere karşı olumsuz beklentiler içinde olduklarında ise tam tersi davranışlar sergilemektedirler (Chang, 2011). Yapılan çalışmalar Pymalion etkisinin varlığını göstermekle birlikte, öğrenci başarısının tümüyle öğretmen beklenti ve davranışıyla açılanamayacağını, kısmen öğrencilerin benlik kavramı tarafından belirlendiğini (Friedrich vd., 2015), kısmen de öğrenci motivasyonu ve coşkusu tarafından belirlendiğini (Chang, 2011) ortaya koymaktadır.

Coşku-coşkusuzluk: Öğretmen coşkusunun öğrenci motivasyonunu artırdığı bulgusu, etkin öğretim veya öğrenci motivasyonu için öğretmen coşkusunun önemli olduğuna dair yapılan tespitleri (Gorham ve Millette, 1997; Hisley ve Kempler, 2000; Dörnyei, 2001, Dörnyei ve Ushioda, 2011; Yıldırım vd. 2015) desteklemektedir. Coşkunun bulaşıcı bir nitelik 
taşıdığı dikkate alındığında ortaya çıkan sonucun beklentilere uygun olduğu söylenebilir. Thoonen, Sleegers, Peetsma ve Oort (2011), öğretmen coşkusu ile öz yeterlik algısı arasında ilişki olduğunu, daha yüksek öz yeterlik algısına sahip öğretmenlerin daha coşkulu olduklarını belirtmektedir. Collins (1978), öğretmenlerin coşkusunun sekiz göstergesini belirlemiştir: Hızlı, değişik, canlandırıcı bir sesle konuşma; alabildiğine açık gözler; sık gösterilen jestler; değişik dramatik vücut hareketleri; çeşitli yüz ifadeleri; enerjik bir duruş; birçok sıfat da dahil olmak üzere farklı kelime kullanımı ve öğrencilerin fikir ve duygularına istekli, canlı bir şekilde tepki verme (Akt: Stewart, 1989). Cruickshank, Bainer ve Metcalf (1995) ise coşkulu öğretmenlerin; kendilerine güvenilebileceği, yaptıklarından haz aldıkları, öğrencilerine güvendikleri ve onlara sayg1 duydukları mesajinı verdiklerini ifade etmektedir (Akt: Ubuz ve Sarı, 2009). Türkiye'de öğretmen adayları kendilerini bu coşkudan maalesef uzak hissetmektedirler (Şahin ve Beycioğlu, 2015).

Eşitlik, adalet-gözde öğrenci: Sınıfta öğretmenin öğrencilere eşit ve adaletli davranmasının ögrrenci motivasyonunu artırdığı, sınıfta gözde öğrenci olmasının öğretmenin eşitliğe aykırı ve adaletsiz davrandığı algısını oluşturarak diğer öğrencilerin motivasyonunu düşürdüğü bulgusu, önceki araştırma sonuçlarıyla (Berti, Molinari ve Speltini, 2010; ChoryAssad, 2002; Ekinci ve Burgaz, 2009; Molinari, Speltini ve Passini, 2013) benzerlik göstermektedir. İnsan motivasyonunun temelinde, insanların kendilerine eşit davranılması isteği yattığına ilişkin eşitlik kuramı, Adams tarafından geliştirilmiştir (Kanfer, 1990). Bu kurama göre, insanlar kendi çaba ve elde ettikleriyle kendilerine benzer kişilerin çaba ve elde ettikleri arasında bir karşılaştırma yapar. Karşılaştırma sonucunda eşitsizlik algısına ulaşırsa motivasyonu düşer (Ehrhardt-Madapathi, Pretsch ve Schmitt, 2017). Örgütler için geliştirilen eşitlik teorisi, eşitliğin, adalet kavramının bir boyutu olduğu düşüncesinden hareketle örgütsel adalet olarak çalışılmaya başlanmış ve endüstriyel/örgütsel psikolojiden gelen bu kavram sınıf adaleti olarak, öğretmen davranışlarını betimlemek, açıklamak için kullanılmaya başlanmıştır (Chory-Assad, 2002). Yapılan sınıf adaleti araştırmaları, bu örgüt temelli kavramsallaştırmanın, öğretim ortamları için de geçerli olduğunu desteklemektedir. Horan, 
Chory ve Goodboy (2010) yaptıkları çalışmada, sınıf adaleti ile ilgili boyutların, örgütsel adalet ile aynı olduğunu tespit etmişler ve aynı boyutlarda sınıf adaleti algılarını etkileyen konuları tespit etmişlerdir. Buna göre; dağıtımcı adalet konuları arasında notlar, notların iyileştirilmesi için fırsatlar, öğretmenin duyguları etkilemesi ve cezalandırmalar yer alıyor; işlemsel adalet konuları, not verme süreçleri, bütünleme/gecikme politikaları, programlama/iş yükü, sınavlar için bilgi, geribildirim, öğretmen hatası, vaatlerin yerine getirilmemesi, ders süreçleri ve pekiştirme politikalarının uygulanmamasını içermektedir; etkileşim adaleti konuları arasında ise duyarsızlık/kabalık, aptallığı ima etmek ya da söylemek, cinsiyetçi/rrkçı/önyargılı yorumlar, gözde öğrenci seçmek, öğrencileri haksız şekilde suçlamak ve öğretmenin duyguları etkilemesi yer almaktadır.

Tutarlılık-tutarsızlık: Öğretmenin tutarlılığı, ruh haline veya duruma göre sınıf kuralları ve uygulamalarını değiştirmemesidir. Bu çalışmada tespit edilen öğretmenin tutarlı olmasının öğrenci motivasyonunu artırdığı bulgusuna benzer şekilde Şahin (2011) de, öğretmenlerin "söyledikleriyle yaptıkları tutarlı olmalıdır" bulgusuna ulaşmıştır. Ekinci ve Burgaz'ın (2009) çalışmasında da, öğretmenlerin sınıf kurallarını kararlı, sürekli ve tutarlı biçimde uygulamamaları, öğrencilerin istenmeyen davranışlarının ortaya çıkmasına neden olduğu tespit edilmiştir. Alkan'ın (2007) çalışmasına göre, erkek öğretmenlerin ve kıdemi düşük öğretmenlerin daha sınıfta daha tutarsız davranış sergiledikleri, Atıcı'nın (2002) çalışmasına göre de, okul bazında öğretmenlerin davranışları arasında bir tutarlılık olmadığı, her öğretmenin bireysel olarak davranışta bulunduğu tespit edilmiştir. Buna göre, öğretmenlerin verdiği ödevi sürekli kontrol etmesi, öğrencilerin belli davranışına her seferinde yaptırım uygulaması ya da iyi davranışların önemsenmesi, söyledikleri ile yaptıklarının tutarlı olması, örneğin sınıf kurallarına kendisinin de uymasının öğrenci motivasyonunu artırdığı söylenebilir. Aksi durumda öğrenciler, kurallara ve öğretmene olan saygılarını, sonuçta da motivasyonlarını yitirebilirler. Tutarlılık, aynı zamanda eşitlik-adalet ile de bağlantılıdır. Aynı davranışlara tutarlı bir şekilde aynı tepkileri veren bir öğretmen, adil olarak algılanırken, farklı tepkiler veren ya da hiç tepki vermeyen öğretmen, kararsız veya haksız olarak suçlanabilecektir. 
Açık sını iklimi oluşturma-kapalı sınıf iklimi oluşturma: Sınıf iklimi, öğrencilerin sınıf içindeki olumlu ve olumsuz durumlar karşısında, sınıf arkadaşları ve öğretmeni hakkındaki algılarını ifade etmektedir (Anderson, Hamilton ve Hattie, 2004). Her öğrenci kendi sınıf ortamını anlamaya çalışsa da, öğrenciler ve öğretmen arasında ortak bir duygu vardır. Bu nedenle sınıf iklimi, sınıfın herkes tarafından paylaşılan genel bir duygudur (Fraser ve Treagust, 1986; Akt: Barr, 2016). Dersliklerin belirgin psikolojik ortamlara sahip olduğunun ilk defa Lewin, Lippitt ve White (1939) tarafından fark edilmesiyle sınıf iklimi araştırmalarının 1939 y1lında başladığ1 düşünülmektedir (Patrick, Kaplan ve Ryan, 2011). Konuya başlangıçtaki bu anlamı açısından bakıldığında; sınıf iklimi, sınıfta öğrenme öğretme etkinlikleri sırasında öğretmen-öğrenci ve öğrenciöğrenci etkileşimine ilişkin algılanan hissediş olarak tanımlanabilir. Bu hissediş psikolojiktir. Çünkü öğrencilerin akademik başarıları, öz yeterlik algıları vb. durumlara göre sınıf iklimi farklı şekillerde algılanabilir. $\mathrm{Bu}$ nedenle, aynı öğretmenin farklı sınıflarında farklı iklimler oluşabilmektedir. Bununla birlikte, sınıf iklimi, genellikle öğretmenin bir fonksiyonu olarak görülmektedir (Marsh, Martin ve Cheng, 2008). Farklı bir ifade ile bu araştırmada ortaya çıktı̆̆ gibi, öğretmen davranışlarının sınıf ikliminin belirleyicilerinden olduğu, öğretmenin davranışları ile açı ya da kapalı bir sınıf iklimi oluşturarak öğrenci motivasyonunu etkilediği söylenebilir. Öğretmenin açı ya da kapalı iklim oluşturmada önemli olan davranışlarını, Gokcora (1989) tarafından geliştirilen ölçeğin boyutlarından takip etmek mümkündür (Akt: Mazer ve Hunt, 2008): Öğretmenin yaklaşımı (rahatsız edici-rahat), öğretim yaklaşımı (anlatımtartışma), mizah duygusu (ciddi-esprili), sınıf kontrolü (gevşek-sıkı), teşvik etme (cesaret kırıcı-teşvik edici), sınıf atmosferi (rahat ve gergin), tartışmaya yaklaşım (yargılayıcı ve açık fikirli), öğrencilere davranışı (eşit-eşit değil), öğrencilerin sorunlarına karşı empati kurmak (ilgisiz ve ilgili), öğretim yöntemi (heyecanlı- sıkıcı). Görüldüğü gibi Gokcora tarafından tespit edilen öğretmen davranışları ile bu araştırmada açık ya da kapalı iklime neden olduğu tespit edilen öğretmen davranışları birbirine benzemektedir. Ayrıca, açı iklimin öğrencileri motive ettiği bulgusu 
önceki araştırma bulguları ile uyumludur (Anderson vd. 2004; Cheema ve Kitsantas, 2014).

Alan bilgisi-alan bilgisinde yetersizlik: Öğretmenin mesleki yeterlikleri genel olarak genel kültür, öğretmenlik meslek bilgisi ve alan bilgisi olarak ifade edilmektedir. Öğretmenlerin konu alan bilgisindeki yetersizliklerinin, bazı materyalleri kullanmada rahat hareket edememelerine ya da araç gereçleri öğrenciye konuyla ilgili yanlış bilgi verecek şekilde kullanmalarına ve öğrencilerin konuyla ilgili sorularını yanıtlayamamalarına neden olacağı (Davis, 2003; Akt: Baştürk, 2009) dikkate alındığında öğretmenin alan bilgisindeki eksikliğinin öğrenci motivasyonunu düşürmesi beklenebilir. Bu araştırmada, beklentilere uygun olarak meslek bilgisi ve alan bilgisi yeterli olan öğretmenlerin öğrenci motivasyonunu artırdığı, meslek bilgisi ve alan bilgisi yetersiz öğretmenlerin öğrenci motivasyonunu düşürdüğü tespit edilmiştir. Elde edilen bu bulgu, Gorham ve Millette (1997); Kearney vd. (1991), Y1ldırım vd. (2015) tarafindan yapılan çalışmalarda elde edilen bulguları da destekler niteliktedir.

Dikkat çekme-konuşma yetersizliği (sorunlarn): Elde edilen bulgulara göre, öğretmenin öğrencinin dikkatini çekmeye yönelik davranışları, aynı zamanda öğrenci motivasyonunu artırırken, öğretmenin konuşma yetersizliği (sorunları), öğrencinin motivasyonu düşürmektedir. Bu bulgu, önceki araştırma bulgularını da (Kearney vd., 1991; Dörnyei, 2001; Gorham ve Christophel, 1992) destekler niteliktedir. Akkaya (2012) tarafından yapılan taramaya göre; çekingen, tekdüze ve dağınık konuşmak, sözcükleri tekrarlamak, kaba ve argo sözler kullanmak, konuşmayı gereksiz yere uzatmak, konuşma sırasında başkalarıyla alay etmek, dinlemeyi bilmemek, sert, kırıcı ve yapmacık davranmak vb. davranışlar konuşma sorunları olarak tanımlanmaktadır. Öğretmenin işinin temelde iletişim, konuşma becerilerine dayalı olduğu dikkate alındığında, öğretmenin konuşma sorunlarının öğrencilerin dikkatinin dağılmasına ve motivasyonlarının düşmesine neden olmasının doğal bir durum olduğu ifade edilebilir. Atıcı (2001), öğrencinin dikkatini çeken stratejiler kullanabilen öğretmenlerin yüksek yetkinliğe sahip öğretmenler olduğunu tespit etmiştir. Bu nedenle, konuşma yetersizliği sergilemeyen, dikkat 
çekme davranışını sergileyebilen öğretmenlerin daha yetkin oldukları söylenebilir.

Şiddet: Şiddetin psikolojik, fiziksel ya da pasif olması fark etmeksizin her üç türü de öğrenci motivasyonunu azaltan öğretmen davranışı olarak tespit edilmiştir. Bu tespit, Ünal (2013), Ünal ve Gürsel'in (2015) bulgular1 ile de uyumludur. Ünal'ın (2012), öğretmenlerin öğrenciye yönelik sapma davranışlarının şiddet içerikli olduğu ve sapma davranışlarının en büyük bölümünü oluşturduğu dikkate alındığında, Türkiye'de öğretmen şiddeti kaynaklı öğrenci motivasyon düşüklügünün olması beklenebilir.

Ulaşılmazlık: Öğrencilerin, ihtiyaç duyduklarında özellikle de okul zamanında okulda öğretmenleri aradıklarında bulamamaları, öğretmenin ulaşılmaz olması durumunda motivasyonları düşmektedir. Bu bulgu, önceki araştırma sonuçlarını da (Gorham ve Christophel, 1992; Gorham ve Millette, 1997; Dörnyei, 2001; Kearney vd., 1991) destekler niteliktedir.

Yetersizlik: Öğretmenin yetersizlik davranışları; sınıf kontrolü yetersizliği, mizah duygusu yetersizliği, insan ilişkileri yetersizliği, konuşma yetersizliği (sorunları), alan bilgisi yetersizliği olarak beş boyuttan oluşmaktadır. Kearney vd. (1991), öğretmen yetersizliğinin, öğrenci motivasyonunu azaltan davranışlardan olduğunu ve öğretmenin yetersizlik davranışlarının, öğretmenin yaptığı işe ilişkin bilgi sahibi olmadığını, öğretmenin dersi ve öğrencileri önemsemediğini gösterdiğini tespit etmişlerdir. Zhang'ın (2007) araştırmasına göre, tüm ülkelerde en yaygın istenmeyen davranış yetersizliktir ve öğretmenlerin yetersizlik davranışı, öğrencilerin motivasyonunu düşürmektedir. Ekinci ve Burgaz (2009), öğretmenin temel yetersizliklerinden birisinin sınıf yönetimi konusunda olduğunu tespit etmişlerdir. Bu araştırmada da, sınıf yönetiminin özellikle de sınıf kontrolünün öğrenci motivasyonunu azaltan bir öğretmen yetersizliği olduğu tespit edilmiştir. Bu da beklenen bir durumdur. Kuralı olmayan, kurallara uymaya zorlanmayan/zorlanamayan, gürültülü bir sinıfta öğrenci motivasyonunun ortaya çıkması söz konusu olamaz. Öğretmenin derslerde mizahı kullanma yetersizliğinin öğrenci motivasyonunu düşürdüğü bulgusu da önceki çalışmalarla beklentiler doğrultu- 
sunda uyumludur (Gorham ve Christophel, 1992; Gorham ve Millette, 1997; Mazer ve Hunt, 2008; Lamb ve Wedell 2014; Zhang, 2007). Robinson (2017), “Başarıyı artırmanın yolu, öğretmenin ve öğrenmenin bir ilişkisi olduğunu fark etmektir. Öğrenciler onlarla bağlantı kuran ve en önemlisi onlara inanan öğretmenlere ihtiyaç duyarlar." diyor. Muhtemelen bu ifadeye itiraz edecek eğitimci ya da araştırmacı yoktur. Bizim araştırmamızda tespit ettiğimiz şekilde, önceki araştırmalar da (Lamb, 2017; Maulana vd., 2016; Opdenakker ve Maulana, 2010; Akt: Opdenakker vd., 2012) öğretmen-öğrenci arasındaki insan ilişkilerinin iyi olmamasının öğrenci motivasyonunu düşürdüğü tespit edilmiştir.

Kişisel ilgi: Brophy ve Good'a (1986) göre, bir öğrencinin öğretmen tarafından göz ardı edildiğini veya desteklenmediğini hissetmesi ya da öğrenme deneyimini etkilememesi söz konusu olduğunda öğrenciler bunu olumsuz olarak deneyimlerler (Akt: Wosnitza ve Nenniger, 2001). Farklı bir ifade ile öğrenciler, öğretmenlerinden okul çalışmalarına verilen akademik desteğin ötesinde kendilerine yönelmiş bir ilgi, merak ve empati beklemektedirler (Erben Keçici vd., 2013a, 2013b). Wlodkowski'ye (1986) göre, öğretmenler öğrencileri gerçekten dinleyerek onlara önem verdiğini, kişisel ilgi gösterdiğini hissettirebilirler (Akt: Dörnyei, 2001). Dörnyei (2001); öğrencileri selamlama, adlarını hatırlama, gülümseme, ilginç özelliklerine dikkat etme, okul dışı hayatlarını öğrenme, hobilerine ilgi gösterme, kişisel çabalarını fark etme, daha önce konuştuklarını hatırlama, konuşurken kişisel konuları ekleme, devamsız öğrencilere ödev gönderme vb. davranışların sergilenmesinin öğrenciye kişisel ilgi göstermek olduğunu ve öğrenci motivasyonunu artıracağını belirtmektedir.

Hazırlık-planlama: Öğretmenin derse hazırlıklı olarak gelip, planı doğrultusunda uygulama yapması, karmaşayı önlemesine, dersi düzenli şekilde işlemesine, öğrencilere dönüt vermesine katkı yapar. Öğretmenin bu davranışı, sonuçta öğretim etkinliklerinin akıcı bir şekilde sürdürülmesini, dersin etkili olmasını, öğrencinin öğrenmesini sağlayacaktır. Dersin etkili olması, öğrencinin öğrenmesinin de öğrenci motivasyonunu artırması doğaldır. Burada dikkat edilmesi gereken husus, öğretmenin plan yapmasının tek başına yeterli olmadığı, öğretmenin hazırlamış olduğu planı hayata geçirmesinin derste düzeni sağladığıdır. 
Herzberg çift faktör teorisi adını verdiği motivasyon kuramını ortaya koyduğu çalışmasında, motivasyonun karşıt anlamının motivasyonsuzluk olmadığı, bir işin motivasyonsuzluk yaratan özellikleri ortadan kaldırıldığında motivasyonun artmadığını ortaya koymuştur (Robbins, Decenzo ve Coulter, 2013). Aynı durum öğrenci motivasyonu için de söz konusu olabilir. Şekil 1'den takip edilebileceği gibi; öğretmenin şiddet, coşkusuzluk, gözde öğrenci, tutarsızlık, kapalı sınıf iklimi oluşturma, ulaşılmazlık ve yetersizlik göstermesi davranışları öğrencinin motivasyonunu düşürmektedir. Peki, bu davranışlar sergilenmediğinde öğrenci motivasyonu artmakta midır? Bu sorunun cevabi kısmen evet, kismen hayır olarak verilebilir. Kısmen hayır cevabı verilebilecek bölümüne göre, motive edici öğretmen davranışlarıyla eşleşmeyen motivasyonu azaltan davranışlar (Şekil 1'de çift yönlü ok ile eşleşmeyenler -şiddet, ulaşılmazlık, yetersizlik-) ortadan kalktığında, motivasyon ortaya çıkmaz. Kısmen hayır cevabı verilebilecek kısmına göre ise, öğretmenin coşkusuzluğunun yerini coşku, gözde öğrenci yerini eşit-adil davranış, tutarsızlığın yerini tutarlılık, kapalı sınıf iklimi oluşturmanın yerini açık iklim aldığında öğrenci motivasyonu ortaya çıkabilecektir. Bunun yanında öğrenciye kişisel ilgi göstermek ve hazırlık/planlama davranışı öğrenci motivasyonunu artırmakta ancak bu davranışlar yapılmadığında bu durum öğrencinin motivasyonunu düşürücü bir etki yapmamaktadır.

Çalışmada elde edile sonuçlara dayalı olarak, sınıflarında etkili olmak isteyen öğretmenlerin öğrenci motivasyonunu azaltan davranışları (coşkusuzluk, gözde öğrenci, tutarsızlık, kapalı sınıf iklimi oluşturma, ulaşılmazlık ve şiddet -fiziksel şiddet, psikolojik şiddet ve pasif saldırganlık) sergilememeleri, yetersiz oldukları (alan bilgisi yetersizliği, konuşma sorunları, mizah duygusu, sınıf kontrolï) alanlar varsa, bu yetersizliklerini ortadan kaldırmaya çalışmaları; öğrenci motivasyonunu artırmak için ise öğrenci motivasyonunu artıran davranışları (kişisel ilgi, hazırlık/plan, yüksek başarı beklentisi, coşku, eşitlik/adalet, tutarlılık, açık sınıf iklimi, alan bilgisi ve dikkat çekme) sergilemeleri önerilebilir. Tabi ki; öğretmenlere şu davranışları yapın ya da yapmayın önerisi, onların davranışını değiştirmelerine yeterli değildir. Bunun için öncelikle, öğretmenlerin yapmaları ya da yapmamaları gereken davranışlar konusunda öğretmen adaylarına hizmet öncesinde bilinç kazandırılmaya çal1- 
şılmalıdır. İkinci olarak öğretmenler için okullarında mesleki gelişimi sağlayabilecekleri, okul temelli mesleki gelişim kültürü geliştirilmeli ve mesleki gelişim uygulamaları yapılmalıdır.

Araştırmada elde edilen bulgulara dayalı olarak yapılacak nicel çalışmalar kapsamında yapılacak açımlayıcı ve doğrulayıcı faktör analizi ile bu araştırmada belirlenen davranış boyutları gözden geçirilebilir. Bu şekilde geliştirilecek ölçek vasıtasıyla, öğrenci motivasyonunu artıran ve azaltan öğretmen davranışlarının yaygınlığı ve etkileri öğrenci ve öğretmen bakış açılarıyla ayrı ayrı tespit edilebilir. 
EXTENDED ABSTRACT

\title{
Investigation of Teacher Behavior Increasing and Reducing Student Motivation
}

\author{
* \\ Abdullah Sürücü - Ali Ünal \\ Necmettin Erbakan University
}

\section{Introduction}

Motivation is a dynamic state of arousal that initiates cognitive and motor processes, directs, coordinates, strengthens, terminates and evaluates them by selecting and ordering of the first wishes in a person and desires and getting them into the action (Dörnyei and Ushioda, 2011). Educational researchers and practitioners state that the most critical factor is the motivation of the students for the success of the student and continuation of the success (Maulana et al., 2011; Orhan Özen, 2017; Robinson, 2017). Maulana et al. (2016) emphasize the need to focus on teacher to increase the motivation of students. Other researchers state that the task of the teacher should be to discover students' state of being motivated to learn, push and help them to maintain their motivation (Deniz et al., 2006; Slavin, 2013). Gorham and Christophel (1992), determined that teachers' negative behaviors that reduce motivation have more effect than positive behaviors that increase motivation. Dörnyei (2001) states that the enthusiasm of teachers, their anticipation, and commitment to learning of their students, their relationships with the students and students' relationships with their parents are effective in student motivation.

\section{Objective}

This research aims to determine the behaviors of teachers that increase and decrease student motivation. 


\section{Method}

This study was conducted in a phenomenological pattern from qualitative research design. The reason for the selection of this pattern is that the phenomenological study defines the common meaning of more than one person's experiences with a phenomenon (Creswell, 2013) and this approach is suitable for studying effective, emotional and often intense human experiences (Merriam, 2013).

\section{Study Group}

The study group of this study consists of the undergraduate or graduate students of theology faculty receiving pedagogical formation education at Necmettin Erbakan University in the academic year 2016-2017. The study group consists of a total of 294 teacher candidates, 240 are female and 54 are male.

\section{Collection of the Data}

The data were collected through an open-ended survey. Candidate teachers were asked two questions; İmam Hatip High School teachers were asked to answer thinking about vocational school teachers and those who graduated from other high schools were asked to answer thinking about teachers of Religious Culture and Moral Knowledge. Firstly, the following question was asked: "Has there been a teacher who made you think that you should work harder, who you think motivated you? If yes, write the behaviors of this teacher that motivated you in details." Secondly, the same question was asked about the behavior that decreased the motivation.

\section{Analysis of the Data}

Content analysis was used to analyze the data. The data was primarily encoded and the codes were integrated under the categories and the categories were integrated under the themes taking into account similari- 
ties. During the analysis process, the qualitative data analysis program Nvivo was utilized.

\section{Findings}

\section{Teacher Behaviors that Increase the Motivation of Students}

Teacher behaviors that increase the motivation of the students consist of the themes of personal interest, preparation/planning, high success expectation, enthusiasm, equality and justice, consistency, open class climate, field knowledge and drawing attention.

\section{Teacher Behaviors that Decrease the Motivation of Students}

Teacher behaviors that reduce the motivation of students are divided into the themes of lack of enthusiasm, favorite student, inconsistency, closed class climate, violence, inaccessibility, incapacity themes.

\section{Discussion and Conclusion}

Teacher's having high expectations for students increases the student motivation. Teacher enthusiasm has been found to increase student motivation but teachers in Turkey are unfortunately far from feeling this enthusiasm (Şahin and Beycioğlu, 2015). It has been determined that teacher's treating equally and fairly to the students increases the student motivation, however, perceptions of unfair behavior and contrary to equality decrease the students' motivation. While the consistency between what teachers say and do increase student motivation, in the opposite case, students may lose their motivation.

It can be said that teacher's behavior influences student motivation by creating an open or closed class climate. It has been determined that teachers who have sufficient vocational and field knowledge increase the student motivation and inadequate teachers reduce student motivation. While teacher's behaviors to attract student's attention increase the motivation of the student, the teacher's speech problems decrease the motiva- 
tion of the student. All types of violence (psychological, physical or passive) have been identified as teacher behaviors that reduce student motivation. When students cannot find teachers and when they need them and the teacher is inaccessible, it reduces the motivation of students. It has been found that the classroom management, especially class supervision, is a teacher inadequacy reducing student motivation. It has been determined that inability of teachers to use humor in lessons reduces student motivation. It has been determined that the lack of good teacherstudent relationships reduces student motivation. Teacher's coming prepared for the course, implementing in the direction of a plan will contribute to the learning and motivation of the student.

Teacher's violence, lack of enthusiasm, favorite students, inconsistency, creating a closed class climate, inaccessibility and inadequacy reduce the motivation of the students. Additionally, showing personal interest in students and preparation/planning behavior increase student motivation, however, this behavior does not have a reducing effect on the motivation of students. Based on the results, the consciousness of behaviors to do or not to do should be tried to be brought to teacher candidates before the service. In quantitative studies, behavioral dimensions identified in this study can be observed; the prevalence and effects of teacher behaviors can be determined separately from student and teacher perspectives.

\section{Kaynakça / References}

Akkaya, A. (2012). Öğretmen adaylarının konuşma sorunlarına ilişkin görüşleri. Mustafa Kemal Üniversitesi Sosyal Bilimler Enstitüsü Dergisi, 9(20). 405-420.

Alkan, H. B. (2007), İlköğretim öğretmenlerinin istenmeyen davranışlarla baş etme yöntemleri ve okulda şiddet (Yayımlanmamış Yüksek Lisans Tezi). Niğde Üniversitesi, Niğde.

Anderson, A., Hamilton, R. J. ve Hattie, J. (2004). Classroom climate and motivated behaviour in secondary schools. Learning Environmental Research, 7(3), 211-225. https://doi.org/10.1007/s10984-0043292-9 
Atıcı, M. (2001). Yüksek ve düşük yetkinlik düzeyine sahip öğretmenlerin sınıf yönetimi stratejileri. Kuram ve Uygulamada Eğitim Yöneti$m i, 28,483-499$.

Atıcı, M. (2002). Öğrenci istenmeyen davranışlarıyla baş etmede Türk ve İngiliz öğretmenlerin kullandıkları yöntemlerin karşılaştırılması. Ĕ̆itim Yönetimi Dergisi, 29, 9-26.

Barr, J. J. (2016). Developing a positive classroom climate. The IDEA Center.

Erişim: https://www.ideaedu.org/Portals/0/Uploads/Documents/IDEA\% 20Papers/IDEA\%20Papers/PaperIDEA_61.pdf

Baştürk, S. (2009). Ortaöğretim matematik öğretmen adaylarına göre fen edebiyat fakültelerindeki alan eğitimi. İnönü Üniversitesi Eğitim Fakültesi Dergisi, 10(3), 137-160.

Berti, C., Molinari, L. ve Speltini, G. (2010). Classroom justice and psychological engagement: Students' and teachers' representations. Social Psychology of Education, 13, 541-556. doi: 10.1007/s11218-0109128-9

Chang, J. (2011). A case study of the "pygmalion effect": Teacher expectations and student achievement. International Education Studies, 4(1), 198-201.

Cheema, J. R. ve Kitsantas, A. (2014). Influences of disciplinary classroom climate on high school student self-efficacy and mathematics achievement: A look at gender and racial-ethnic differences. International Journal of Science \& Mathematics Education, 12(5), 12611279. https://doi.org/10.1007/s10763-013-9454-4

Chory-Assad, R. M. (2002). Classroom justice: Perceptions of fairness as a predictor of student motivation, learning, and aggression. Communication Quarterly, 50(1), 58-77, doi: 10.1080/01463370209385646

Creswell, J. W. (2013). Nitel araştırma yöntemleri: Beş yaklaşıma göre nitel araştırma ve araştırma deseni. (M. Bütün ve S. B. Demir, Çev. Edt.). Ankara: Siyasal Kitapevi.

Deniz, M., Avşaroğlu, S. ve Fidan, Ö. (2006). İngilizce öğretmenlerinin öğrencileri motive etme düzeyleri. İnönü Üniversitesi Eğitim Fakültesi Dergisi, 11(Bahar), 61-73. 
Dörnyei, Z. ve Ushioda, E. (2011). Teaching and researching motivation (2nd Ed.). Pearson, Harlow.

Dörnyei, Z. (2001). Motivational strategies in the language classroom. Cambridge: Cambridge University Press.

Ehrhardt-Madapathi, N., Pretsch, J. ve Schmitt, M. (2017). Effects of injustice in primary schools on students' behavior and joy of learning. Social Psychology of Education, 20, 1-33. https://doi.org/10.1007/s11218-017-9416-8

Ekinci, C. E. ve Burgaz, B. (2009). İstenmeyen öğrenci davranışlarının öğretmen ve okuldan kaynaklanan nedenleri. Sosyal Bilimler Dergisi, 22, 91-111.

Erben Keçici, S., Beyhan, Ö. ve Sönmez Ektem, I. (2013a). İstenmeyen öğretmen davranışları ölçme aracı geliştirilmesi. The Journal of Academic Social Science Studies, 6(3), 1043-1065.

Erben Keçici, S., Beyhan, Ö. ve Sönmez Ektem, I. (2013b). Agressive teacher behaviorsand its'affects on students. Asian Journalof Management Sciences \& Education (AJMSE), 2(2), 15-25.

Friedrich, A., Flunger, B., Nagengast, B., Jonkmann, K. ve Trautwein, U. (2015). Pygmalion effects in the classroom: Teacher expectancy effects on students' math achievement. Contemporary Educational Psychology, 41 , $1-12$. http://dx.doi.org/10.1016/j.cedpsych.2014.10.006

Gorham, J. ve Christophel, D. M. (1992). Students' perceptions of teacher behaviors as motivating and demotivating factors in college classes. Communication Quarterly, 40(3), 239-252. doi: 10.1080/01463379209369839

Gorham, J. ve Millette, D. (1997). A comparative analysis of teacher and student perceptions of sources of motivation and demotivation in college classes. Communication Education, 46(4), 245-261. doi: 10.1080/03634529709379099

Hisley, J. ve Kempler, T. (2000). What's everybody so excited about?: The effects of teacher enthusiasm on student intrinsic motivation and vitality. Journal of Experimental Education, 68(3), 217-236. doi:10.1080/00220970009600093

Horan, S. M., Chory, R. M. ve Goodboy, A. K. (2010). Understanding students' classroom justice experiences and respon- 
ses. Communication Education, 59(4), 453-474. http://dx.doi.org/10.1080/03634523.2010.487282

Kanfer, R. (1990). Motivation theory and industrial and organizational psychology. In M. D. Dunnette \& L. Hough (Edt.), Handbook of industrial and organizational psychology (pp.75-130). Palo Alto, CA: Consulting Psychologists Press.

Kearney, P., Plax, T. G., Hays, L. R. ve Ivey, M. J. (1991). College teacher misbehaviors: What students don't like about what teachers say or do. Communication Education, 53, 40-55.

Lamb, M. (2017). The motivational dimension of language teaching. Language Teaching, Surveys and Studies, 50(3), 301-346. doi:10.1017/S0261444817000088

Lamb, M. ve Wedell, M. (2014). Cultural contrasts and commonalities in inspiring language teaching. Language Teaching Research, 19(2), 207-224. doi: 10.1177/1362168814541716

Marsh, H. W., Martin, A. J. ve Cheng, J. H. S. (2008). A multilevel perspective on gender in classroom motivation and climate: Potential benefits of male teachers for boys? Journal of Educational Psychology, 100(1), 78-95. doi:10.1037/0022-0663.100.1.78

Maulana, R., Opdenakker, M-C. ve Bosker, R. (2016). Teachers' instructional behaviors as important predictors of academic motivation: Changes and links across the school. Learning and Individual Differences, 50, 147-156. doi: 10.1016/j.lindif.2016.07.019

Maulana, R., Opdenakker, M-C., den Brok, P. ve Bosker, R. (2011). Teacher-student interpersonal relationships in Indonesia: Profiles and importance to student motivation. Asia Pacific Journal of Education, 31(1), 33-49. doi: 10.1080/02188791.2011.544061

Maulana, R., Opdenakker, M-C. ve Bosker, R. (2013). Teacher-student interpersonal relationships do change and affect academic motivation: A multilevel growth curve modelling. British Journal of Educational Psychology, 84, 459-482. doi:10.1111/bjep.12031

Mazer, J. P. ve Hunt, S. K. (2008). The effects of instructor use of positive and negative slang on student motivation, affective learning, and classroom climate. Communication Research Reports, 25, 44-55. 
Merriam, S. B. (2013). Nitel araştırma: Desen ve uygulama için bir rehber. S. Turan (Çev. Ed.). Ankara: Nobel.

Molinari, L., Speltini, G. ve Passini, S. (2013). Do perceptions of being treated fairly increase students' outcomes? Teacher-student interactions and classroom justice in Italian adolescents. Educational Research and Evaluation, 19(1), 58-76. doi: 10.1080/13803611.2012.748254

Opdenakker, M-C., Maulana, R. ve den Brok, P. (2012). Teacher-student interpersonal relationships and academic motivation within one school year: Developmental changes and linkage. School Effectiveness and School Improvement, 23(1), 95-119. doi:10.1080/09243453.2011.619198

Orhan Özen, S. (2017). The effect of motivation on student achievement. In E. Karadağ (Ed.), The factors effecting student achievement (pp. 35-56). Cham, Switzerland: Springer International Publishing. doi: 10.1007/978-3-319-56083-0_3

Passini, S., Molinari, L. ve Speltini, G. (2015). A validation of the questionnaire on teacher interaction in Italian secondary school students: The effect of positive relations on motivation and academic achievement. Social Psychology of Education, 18(3), 547-559. doi: 10.1007/s11218-015-9300-3

Patrick, H., Kaplan, A. ve Ryan, A. M. (2011). Positive classroom motivational environments: Convergence between mastery goal structure and classroom social climate. Journal of Educational Psychology, 103(2), 367-382. http://dx.doi.org/10.1037/a0023311

Patton, M. Q. (2014). Nitel araştırma ve değerlendirme yöntemleri. M. Bütün ve S. B. Demir, (Çev. Edt.) Ankara: Pegem Akademi.

Rehman, A. ve Haider, K. (2013). The impact of motivation on learning of secondary school students in Karachi: An analytical study. Educational Research International, 2(2), 139-147. www.erint.savap.org.pk

Robbins, S. P., Decenzo, D. A. ve Coulter, M. (2013). Yönetimin esasları: Temel kavramlar ve uygulamalar. (A. Öğüt ve C. Erbil, Çev.) Ankara: Nobel Akademik Yayıncılık. 
Robinson, K. (2017). Yaratıcı öğrenciler: Çocukların geleceğgini düşünenler için eğitimde yaratıcılık devrimi. (D. Boyraz, Çev.) İstanbul: Sola Yayınlar1.

Rubie-Davies, C. M. (2010). Teacher expectations and perceptions of student attributes: Is there a relationship? British Journal of Educational Psychology, 80, 121-135. doi:10.1348/000709909X466334

Slavin, R. E. (2013). Öğrencileri öğrenmeye motive etmek. G. Yüksel (Çev. Ed.), Eğitim Psikolojisi (ss. 284-312). Ankara: Nobel.

Stewart, R. A. (1989). Interaction effects of teacher enthusiasm and student notetaking on recall and recognition of lecture content. Communication Research Reports, 6(2), 84-89. http://dx.doi.org/10.1080/08824098909359838

Stroet, K., Opdenakker, M-C. ve Minnaert, A. (2015). What motivates early adolescents for school? A longitudinal analysis of associations between observed teaching and motivation. Contemporary Educational Psychology, 42, 129-140. doi: 10.1016/j.cedpsych.2015.06.002

Şahin, A. (2011). Öğretmen algılarına göre etkili öğretmen davranışları. Ahi Evran Üniversitesi Ĕ̆itim Fakültesi Dergisi, 12(1), 239-259.

Şahin, İ. ve Beycioğlu, K. (2015). Eğitim fakültesi öğretim elemanlarının öğretmen yetiştirmeye ilişkin görüşleri. İnönü Üniversitesi Eğitim Fakültesi Dergisi, 16(2), 33-50. doi: 10.17679/iuefd.16259330

Thoonen, E. E. J., Sleegers, P. J. C., Peetsma, T. T. D. ve Oort, F. J. (2011). Can teachers motivate students to learn? Educational studies, 37(3), 345-360.

Ubuz, B. ve Sarı, S. (2009). Sınıf öğretmeni adaylarının iyi öğretmen olma ile ilgili görüşleri. Ondokuz Mayıs Üniversitesi Eğitim Fakültesi Dergisi, 28, 53-61.

Ünal, A. (2012). Deviant teacher behaviors and their influence on school rules and interpersonal relationships at school. Eğitim Araştırmalarl, 49, 1-20.

Ünal, A. (2013). Teachers' deviant workplace behaviors: Scale development. Social Behavior and Personality: An International Journal, 41(4), 635-642. 
Ünal, A. ve Gürsel, M. (2015). Negative teacher behaviors from which teacher candidates are affected. Proceedings of Teaching and Education Conferences (ss. 163-168). Amsterdam: International Institute of Social and Economic Sciences. doi: 10.20472/TEC.2015.001.013

Wang, M. T. ve Eccles, J. S. (2013). School context, achievementmotivation, and academic engagement: A longitudinal study of school engagement using a multidimensional perspective. Learning and Instruction, 28 , 12-23. http://dx.doi.org/10.1016/j.learninstruc.2013.04.002

Wosnitza, M. ve Nenniger P. (2001). Perceived learning environments and the individual learning process. In S. Volet \& S. Järvelä (Eds.), Motivation in learning contexts (pp. 171-187). London: Pergamon.

Yan, H. (2009). Student and teacher demotivation in ESL. Asian Social Science, 5(1), 109-12.

Yazıcı, H. (2012). Motivasyon. Y. Özbay, S. Erkan (Ed.), Ĕ̆itim Psikolojisi. Ankara: PegemAkademi.

Yıldırım, A., Ünal, A. ve Sürücü, A. (2015). Effective teacher behaviors based on the opinions of teacher candidates. Proceedings of Teaching and Education Conferences (ss. 195-200). Amsterdam: International Institute of Social and Economic Sciences. doi: 10.20472/TEC.2015.001.017

Zhang, Q. (2007). Teacher misbehaviors as learning demotivators in college classrooms: A cross-cultural investigation in China, Germany, Japan, and the United States. Communication Education, 56, 209-227. doi: 10.1080/03634520601110104

\section{Kaynakça Bilgisi / Citation Information}

Sürücü, A. ve Ünal, A. (2018). Öğrenci motivasyonunu artıran ve azaltan öğretmen davranışlarının incelenmesi. OPUS-Uluslararası Toplum Araştırmaları Dergisi, 8(14), 253-295. DOI: 10.26466/opus.404122 